\title{
Suppletion a
}

Ljuba N. Veselinova

Subject: Morphology, Syntax Online Publication Date: Mar 2017

DOI: $10.1093 /$ acrefore/9780199384655.013.50

\section{Summary and Keywords}

The term suppletion is used to indicate the unpredictable encoding of otherwise regular semantic or grammatical relations. Standard examples in English include the present and past tense of the verb go, cf. go vs. went, or the comparative and superlative forms of adjectives such as good or bad, cf. good vs. better vs. best, or bad vs. worse vs. worst.

The complementary distribution of different forms to express a paradigmatic contrast has been noticed already in early grammatical traditions. However, the idea that a special form would supply missing forms in a paradigm was first introduced by the neogrammarian Hermann Osthoff, in his work of 1899. The concept of suppletion was consolidated in modern linguistics by Leonard Bloomfield, in 1926. Since then, the notion has been applied to both affixes and stems. In addition to the application of the concept to linguistic units of varying morpho-syntactic status, such as affixes, or stems of different lexical classes such as, for instance, verbs, adjectives, or nouns, the student should also be prepared to encounter frequent discrepancies between uses of the concept in the theoretical literature and its application in more descriptively oriented work. There are models in which the term suppletion is restricted to exceptions to inflectional patterns only; consequently, exceptions to derivational patterns are not accepted as instantiations of the phenomenon. Thus, the comparative degrees of adjectives will be, at best, less prototypical examples of suppletion.

Treatments of the phenomenon vary widely, to the point of being complete opposites. A strong tendency exists to regard suppletion as an anomaly, a historical artifact, and generally of little theoretical interest. A countertendency is to view the phenomenon as challenging, but nonetheless very important for adequate theory formation. Finally, there are scholars who view suppletion as a functionally motivated result of language change.

For a long time, the database on suppletion, similarly to many other phenomena, was restricted to Indo-European languages. With the solidifying of wider cross-linguistic research and linguistic typology since the 1990s, the database on suppletion has been substantially extended. Large-scale cross-linguistic studies have shown that the phenomenon is observed in many different languages around the globe. In addition, it appears as a systematic cross-linguistic phenomenon in that it can be correlated with well-defined language areas, language families, specific lexemic groups, and specific slots in paradigms. 


\section{Suppletion}

The latter can be shown to follow general markedness universals. Finally, the lexemes that show suppletion tend to have special functions in both lexicon and grammar.

Keywords: suppletion, stem, affix, word, paradigm, inflection, derivation, grammaticalization, lexicalization, natural morphology, canonical typology, relevance principle

\section{Suppletion}

Suppletion refers to the use of distinct forms to encode regular semantic and/or grammatical relations. Standard examples of the phenomenon in English include the forms of the verb "be" and the verb "go," the degrees of some adjectives, and finally, the non-derived forms of ordinals from corresponding cardinals, cf. (1) below for some introductory examples.

(1)

a.

English (Indo-European, West Germanic) [eng ${ }^{1}$

$\begin{array}{lll}\text { 1SG.PRS } & \text { am } & \begin{array}{l}\text { dance } \\ \text { dances }\end{array} \\ \text { 3SG.PRS } & \text { is } & \text { dance } \\ \text { 2SG/PL.PRS } & \text { are } & \text { danced } \\ \text { 1/3SG.PST } & \text { was } & \text { danced } \\ \text { 2sg/PL.PST } & \text { were } & \text { danced } \\ \text { PST.PARTICIPLE } & \text { been } & \text { dancing } \\ \text {-ing-form } & \text { being } & \text { 'nice' } \\ & \text { 'good' } & \text { nice } \\ \text { POSITIVE } & \text { good } & \text { nicer } \\ \text { COMPARATIVE } & \text { better } & \text { nicest } \\ \text { SUPERLATIVE } & \text { best } & \end{array}$

c.

$\begin{array}{ll}\text { ORDINAL } & \text { CARDINAL } \\ \text { first } & \text { one } \\ \text { second } & \text { two } \\ \text { third } & \text { three } \\ \text { fourth } & \text { four }\end{array}$

In other languages, it is also common to observe suppletion in nominal inflection. A crosslinguistically common case is shown in (2) by data from Russian, where the plural of noun rebënok 'child' is formed by a completely different stem deti.

(2) 


\section{Suppletion}

\begin{tabular}{|c|c|c|c|c|}
\hline \multicolumn{5}{|c|}{$\begin{array}{l}\text { Russian (Indo-European, East Slavonic) [rus], adapted from Corbett }(2007, \mathrm{p} .18)^{2} \\
\text { rebënok'child' }\end{array}$} \\
\hline & singular & plural & singular & plural \\
\hline nominative & rebënok & deti & djadja & djadi \\
\hline accusative & rebënka & detej & djadju & djadej \\
\hline genitive & rebënka & detej & djadi & djadej \\
\hline dative & rebënku & detjam & djade & djadjam \\
\hline instrumental & rebënkom & det'mi & djadej & djadjami \\
\hline locative & rebënke & detjax & djade & djadjax \\
\hline
\end{tabular}

At first glance, suppletion will appear as a rather straightforward phenomenon, easy to identify and study. However, any serious attempt to delimit the concept in a theoretical manner reveals that its definition is a lot more complex than meets the eye. Specifically, issues immediately pertinent to it are long-debated theoretical notions such as word, morpheme, regularity, productivity, and the dichotomy between derivation and inflection. Ultimately, the study of suppletion, or exceptions to regular patterns, involves a careful examination of what constitutes a pattern. Thus the study of suppletion is actually the study of systematicity in language structure.

\subsection{Notes on the Origin of the Concept}

The use of distinct forms to encode regular grammatical relations has been noticed by various authors from very early grammatical-linguistic traditions. Perhaps the best example of such awareness is found in the work of Pānini. This grammarian, cited by Deshpande (1992), observes that there are verbs used only in complimentary distribution according to aspect. Specifically, Pānini lists Sanskrit roots such as $d r ̣ s$ ('look, gaze, behold') and pásya ('look, see'), together with a few others that appear to him as irregular alternations. He also notes that the root $d r s$ is never used with the present/imperfective affixes, but the root pásya is used instead.

Among the neogrammarians, two scholars appear especially important: Bertold Delbrück and Hermann Osthoff. Delbrück (2010[1988]) describes the Latin verbs ìre ('go') and ferre ('carry') as defective and anomalous and the verb esse ('be') as primitive. In this work Delbrück makes a statement that semantically related roots which cannot express all aspects by themselves merge together into one verb (Delbrück, 2010, pp. 273-274). He goes on to say that the clearest division takes place between the present and the aorist and lists a few roots, for instance atsyatí 'eat.present' from ad 'eat' versus jaghása from ghas 'eat.aorist.'

This idea of defectiveness in specific paradigms probably led to the idea that certain forms supply missing forms in them, something initially expressed by Osthoff (1899). This is the first author to use the term Suppletivwesen. He illustrates it by examples mainly from Indo-European languages such as Latin bonus ('good') versus melior ('better'), ferō ('carry') versus tulī ('have carried'), and also by nouns that indicate kinship such as 'father-mother,' 'brother-sister,' gender based nouns for domesticated animals such as 'oxcow, ' 'rooster-hen.' Osthoff is also first off to offer a motivation for suppletion by introducing the concept of Nahbereich (German, "a proximate/adjacent area"). According to him, 


\section{Suppletion}

the use of distinct forms to express different grammatical categories of common words is motivated by the striving of primitive man to split and individualize phenomena that are close to her/him. This would explain why suppletion in Indo-European languages is encountered among words that express notions of everyday necessity, namely verbs such as "be," "give," "go," "see," etc.; nouns that indicate kinship, degree of comparison of adjectives such as "good" and "bad"; ordinal numerals such as "first" and "second"; personal pronouns; and finally the denominations of domesticated animals cited above. Osthoff's idea was later transferred into modern linguistics by the school of Natural Morphology (cf. SECTION 1.3.2 "NATURAL MORPHOLOGY”, for further discussion).

In linguistic theory of the 20th century, suppletion was fully established as a concept with the advent of structuralism, where the relation between form and meaning as well as the understanding of paradigmatic relationships became very important for a synchronic language description. Bloomfield (1926) offered a definition of suppletion in structuralist terms. He used English examples such as go versus went, good versus better. In that work, he made a statement to the effect that, in a given language, suppletion can be identified only after concepts such as stem and affix have been defined for that language. He considered suppletive forms to be non-segmentable units from a morphological point of view.

\subsection{Delimiting the Concept}

\subsubsection{Synchrony vs. Diachrony}

Synchrony and diachrony have been mixed up, at times, with regard to suppletion. Rudes (1980) is representative of this tendency. This author distinguishes between genuine and pseudo-suppletion. Genuine suppletion covers forms that are etymologically different, such as go and went; the present tense forms of the verb "be" in English-am, is, are-are examples of pseudo-suppletion since they go back to one and the same Indo-European etymon. This distinction is not widely accepted. Mel'čuk (1994, p. 355) rejects it explicitly; in the modern scholarship on suppletion, there is agreement that it is untenable to base a theoretical concept on considerations of etymology.

\subsubsection{Affixal vs. Stem Suppletion}

Different kinds of suppletion are distinguished depending on the kinds of linguistic signs it affects. Thus, it is customary to distinguish between affixal and stem suppletion. A case of affixal suppletion is shown in (3) below.

(3)

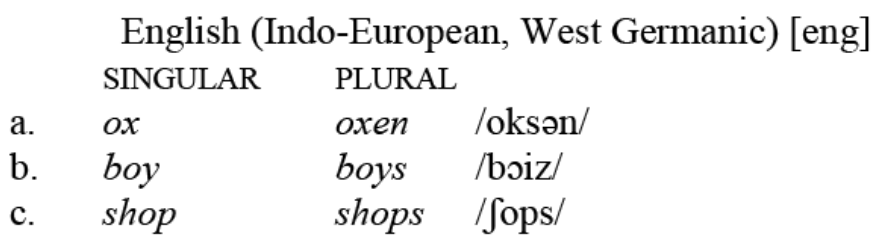




\section{Suppletion}

The plural affix -en in English oxen (3a) is not motivated by any morpho-phonological rules of English, unlike the other plural allomorphs /-z/ or /-s/ as in /boiz/ and /Sops/ for which such motivation is present. Consequently, the plural suffix -en is considered to be suppletive as compared to the phonologically conditioned ones /z/ and /s/ (see Boyè, 2006). A case of stem suppletion is the unpredictable change of stems in a paradigm, as in English go for the non-past tenses and went for the past tense. Discussions of affixal suppletion can be found in Dressler (1985), Carstairs-McCarthy (1992), Mel'čuk (1994), Booij, Lehmann, and Mugdan(2004), and see also Garcia Mayo and Villareal Olaizola (2011) for pertinent data from third language acquisition. It has to be said that, while a number of works in morpho-phonology have been devoted to affixal suppletion, it is unclear how to tell the difference between a suppletive affix and a lexically conditioned allomorph; see also pertinent discussion on this issue in Corbett (2007). This author strongly questions the notion of suppletion when applied to affixes by offering the following motivation:

If affixal suppletion is allowed for, then suppletion ceases to be a special boundary phenomenon requiring specific analysis (and a special term) and rather takes in a substantial proportion of inflectional morphology. (Corbett, 2007, p. 15)

Generally, the concept of suppletion is much more useful for both theory formation and language description when referring to the complimentary distribution of stems rather than that of affixes.

\subsubsection{Formal Difference between Suppletive Forms}

Formally, suppletive forms have been described as strong and weak, as in Dressler (1985). This distinction is introduced to refer to the fact that some forms, such as am versus was, do not share any phonological material (strong suppletion) while others do, such as child: children (weak suppletion). Since it is not always clear where to set the limit for what counts as weak suppletion, Mel'čuk (1994, p. 367) introduces the criterion of uniqueness. The alternation of two paradigmatically related forms counts as suppletive if it is the only one of its kind in the language. Thus child: children counts as an instantiation of weak suppletion in English, whereas strong verbs such as drink: drank do not, since they are part of a pattern, albeit a restricted one that includes six verbs only, as shown here in (4).

\begin{tabular}{ll}
\multicolumn{1}{l}{ English } & \\
PRESENT & PAST \\
drink & drank \\
sink & sank \\
ring & rang \\
sink & sank \\
begin & began \\
swim & swam
\end{tabular}

In more recent work on suppletion, the distinction between strong and weak suppletion appears as full vs. partial suppletion (cf. Corbett, 2007, p. 15). 


\section{Suppletion}

\subsubsection{Suppletive Forms and Unique Paradigms}

Suppletive forms most often alternate within one and the same paradigm. Juge (1998) brings up a rare instance of one and the same suppletive form being used in two different paradigms. This is observed with the Spanish verbs ser 'be' and ir 'go,' which share the same stem, fui-, for the formation of their preterite. Juge (1998) labels this overlapping suppletion.

\begin{tabular}{lllll}
\multicolumn{5}{l}{ Spanish (Indo-European, Italo-Western Romance) [spa] } \\
ser 'be' & \multicolumn{1}{c}{ ir 'go' } \\
& PRESENT & PRETERIT & PRESENT & PRETERIT \\
1SG & soy & fui & voy & fui \\
2SG & eres & fuiste & vas & fuiste \\
3SG & es & fue & va & fue \\
1PL & somos & fuimos & vamos & fuimos \\
2PL & sois & fuisteis & vais & fuisteis \\
3PL & son & fueron & van & fueron
\end{tabular}

While it is most often the case that there is only one suppletive form for a specific slot in a paradigm, alternation between a suppletive and a regular form is also observed, as shown in data from Turkish in (6), below.

(6)

Turkish (Turkic, Common Turkic, Oghuz-Uighur-Kipchak, Oghuz) [tur] Underhill (1976, p.187)

$\begin{array}{llll}\text { one } & \text { bir } & \text { first } & \text { birinci/ilk } \\ \text { two } & i k i & \text { second } & \text { ikinci } \\ \text { three } & \ddot{u} c ̧ & \text { third } & \ddot{u} \text { çüncü } \\ \text { four } & \text { dört } & \text { fourth } & \text { dördüncü }\end{array}$

In Turkish, the suppletive and the regular form are in free variation in many contexts. One important difference between ilk and birinci is that the form ilk is the only one possible for the temporal sense of ordinals such as ilk aşk "the first love in one's life" (chronologically) while birinci is used to indicate first or foremost position in a hierarchy. Thus the phrase birinci aşk means "the first/greatest love of one's life."

Corbett (2007, p. 23) cites an alternation of a regular and a suppletive form in the paradigm of the Russian noun čelovek 'person.' It has a suppletive form ljudi, for most cases in the plural, except for the genitive, where both the suppletive ljudej and the regular čelovek can be used.

\subsubsection{Inflection, Derivation, and Suppletion}

Corbett $(2000,2007)$ restricts the term suppletion to describe exceptions to morphophonological patterns that can be strictly identified as inflection, that is, those expressing categories without which a word in a given language becomes ungrammatical. For instance, verbs in English must always be specified for tense. Consequently, the forms go: went are suppletive in his view; exceptions to derivational patterns are not considered 


\section{Suppletion}

cases of suppletion. Other scholars, such as Dressler (1985, in passim) and Mel'čuk (1994, pp. 362, 381) allow exceptions to any pattern to count as cases of suppletion. Thus, for Mel'čuk the Russian nouns byk 'bull' and korova 'cow.F' are suppletive when considered against the background of a regular derivation of feminine nouns from masculine ones as in (7).

\begin{tabular}{lllll}
\multicolumn{2}{c}{ Russian (-Indo-European, } & East Slavonic) [rus] adapted from (Mel'čuk,1994, p. 362) \\
'elephant' & 'tiger' & 'donkey' & 'cow' \\
MASCULINE & slon & tigr & osël & byk \\
FEMININE & slon-ixa & tigr-ica & osl-ica & korova
\end{tabular}

Following Mel'čuk's line of reasoning, pairs such as cow:bull in English and many other languages should be considered suppletive as well.

With regard to derivation and suppletion, Veselinova (2006, pp. 12-13) points out that the scope and productivity of a derivational pattern matter, when determining whether exceptions to it should be seen as expressing an obligatory distinction, and consequently whether they are to be described as suppletive or not. Gender derivations of the kind illustrated in (7) above, are restricted, in many languages, to a certain class of nouns, which is typically semantically defined. Both in Russian and English, such derivation applies to names of wild animals and names of professions, as in Russian uchitel' versus uchitel'nica, or English waiter versus waitress. Thus, the scope of this derivation is rather limited; exceptions to such derivation are probably best described as semantically related words only. Other kinds of derivational processes apply to all or nearly all members of a certain class. Examples of such derivations include the derivation of manner adverbs from corresponding adjectives in English or the derivation of perfective: imperfective pairs in Slavonic languages (cf. 8, a-c), for a brief illustration). As illustrated by the Slovene data, aspect can be derived by prefixation, as in (8a); suffixation, (8b); stem modification, (8c); or different words/suppletion, (8, d-e). The means for deriving aspect in Slavonic languages are diverse, and the results of the derivation in terms of obtained aspectual value are not always predictable. The derivation of aspect, however, is so widespread in this family that it comes very close to inflection. Consequently, Veselinova (2006, pp. 69-71, 126-133) suggests that perfective: imperfective verb pairs such those in ( $8 \mathrm{~d}-\mathrm{e})$ are to be seen as a borderline cases between lexicalizations of aspect and paradigmatically related suppletive pairs.

\begin{tabular}{llll} 
& \multicolumn{3}{l}{ Slovene (Indo-European, South Slavonic) [slv] } \\
& IMPERFECTIVE & PERFECTIVE & Gloss \\
a. & kriti & po-kriti & 'cover' \\
b. & kupo-va-ti & kupiti & 'buy' \\
c. & za-pirati $i$ 151) & za-préti & 'shut' \\
d. & métati & vreči & 'throw' \\
e. & praviti & reči & 'say'
\end{tabular}




\section{Suppletion}

The student should be also aware of another issue related to delimiting suppletion with regard to inflectional or derivational patterns. Apart from the derivations of gender and aspect discussed above, verbal number pairs are also treated differently with regard to suppletion. Such pairs are shown in (9c), in data from Mupun, a language from Nigeria.

(9)

Mupun (Afro-Asiatic, West Chadic) [sur](Frajzyngier, 1993)

a. püt go out.SINGULAR.ACTION

pú- $a$ - $t \quad$ go out-PLURAL ACTION-go out

b. $y a ̀ \quad$ catch.SG.ACTION

$y \grave{a}-k \quad$ catch-PLURAL ACTION

c. cint beat.SINGULAR.ACTION

nás beat.PLURAL.ACTION

Verbal number, as discussed by Corbett (2000, p. 246ff.), is defined as a category that may reflect the number of times an action is done or the number of participants in an action. Generally, it is important not to confuse verbal number with agreement. The notion of agreement points to the fact that a verb or a verb phrase indexes (agrees with) its subject in number; for instance in French ils étaient fatigues, the predicate étaient fatigués copies the plural of the subject ils. In a language such as French, and in many other IndoEuropean languages, the number of the subject determines the number marked on the verb phrase. In many languages with verbal number, plural verbs indicate all or any one of the following senses: the action designated by the verb is performed several times (iterative), or at several places (distributive); or the action affects or involves several participants. Such senses may be derived from simplex stems by various derivational means as in shown in $(9, a-b)$ or by separate lexemes as in (9c). Such lexemes are labeled as suppletive by many grammar authors, while more theoretically oriented linguistics, such as Corbett (2000, 2007), Mithun (1988), and Mel'čuk (1994) strictly reject such a categorization, with the motivation that the use of pluractional verbs, such those shown in (9) above, is not a matter of syntactic agreement. For instance, in Mupun, the plural marker on the noun that would trigger agreement is optional, see (10).

\begin{tabular}{lll} 
& \multicolumn{1}{c}{ Mupun (Afro-Asiatic, } \\
a. & $n$-tu joos \\
& 1sG-kill.SG & rat \\
& 'I killed a rat' & \\
b. & n-tue & joos \\
& 1sG-kill.PL & rat \\
& 'I killed rats' &
\end{tabular}

Furthermore, while a singular form of a verb is generally ruled out with a plural object (see (11a), a plural verb may be used with a singular object to indicate an action performed with some intensity, or many times, as in (11b). 


\section{Suppletion}

\begin{tabular}{ll}
\hline \multicolumn{4}{l}{ Mupun (Afro-Asiatic, West Chadic) [sur] (Frajzyngier, 1993, p. 59) } \\
a. & *wu cit mo \\
& 3SG.M hit.SG 3PL \\
*he hit them \\
b. \\
wu nás war \\
3SG hit.PL 3SG.F \\
'He hit her many times.'
\end{tabular}

While a separate grammatical category, in many instances, verbal number comes very close to, and at times becomes inseparable from, other categories. In particular, plurality of action is akin to aspect in a number of cases; plurality of participants is not always easy to distinguish from nominal number as reflected in agreement. There are also cases where verbal number evolves into nominal number (Corbett, 2000, p. 256), see also Veselinova (2006, pp. 169-173) on emergent agreement markers out of verbal number pairs.

With regard to delimiting suppletion, it has to be said that, in models where the concept is to be used as a diagnostic for strictly inflectional relations, verbal number pairs such as those shown in (9c) obviously fall out of it. For a rigorous definition and appropriate criteria following this line of thinking, see Corbett (2007).

Following the view of Bybee (1985), where derivation and inflection represent end points of a continuum rather than a dichotomy, Veselinova (2006, pp. 12-13, in passim) considers suppletive forms to represent the gray area between the lexicon and grammar, with some of them, such as the verbal number pair in (9c) and the imperfective-perfective pairs in (8d-e) coming closer to the lexical end, while others, such as the forms of the English verb "be", are closer to the grammatical end. For identifying suppletive forms, she adopts Mel'čuk's criterion of uniqueness and the generality and productivity of a morphological pattern, see further details in (Veselinova, 2006, pp. 46-49). See also further discussion on the relation between suppletion and lexicalization in Section 1.2.6.

It has to be said that for many authors, the availability of ANY patterns, be they morphological or morpho-syntactic is a sufficient condition for the postulation of suppletion.

\subsubsection{Suppletion According to Polarity or Lexicalization of Negation}

The similarities between suppletion and lexicalization were pointed out above in the discussion about suppletion in derivation of aspect and verbal number. Another example of the close connection between suppletion and lexicalization is suppletion according to polarity. This phenomenon is typically illustrated by existential sentences where the positive existential verb is replaced by a negative one. Consider data from Turkish in (12): 


\section{Suppletion}

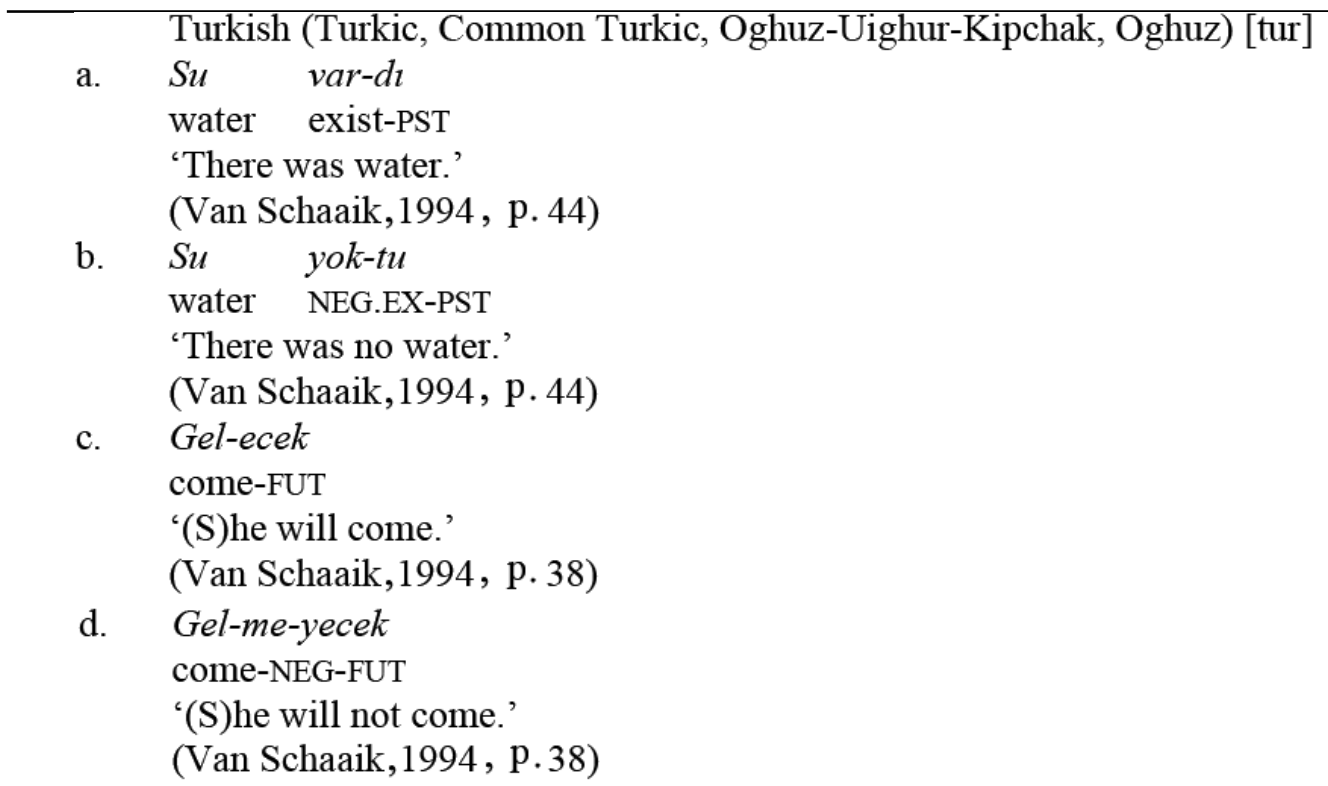

As shown in (12, c-d), in Turkish, verbs are negated by a suffix - $m A$ - where the quality of the vowel is determined by vowel harmony. The suffix $-m A$ - cannot be used for the negation of the existential verb var; a completely different verb yok is used instead; it replaces the affirmative var. Cases similar to the Turkish one in (12) are reported in Veselinova (2006, p. 59) and in the Brown, Chumakina, Corbett, and Hippisley(2003). There is no discussion about the motivation of describing the substitution between affirmative and negative existentials as suppletion in any of these sources.

The substitution of var by yok is the only change that takes place in order to render the positive construction into a negative. Consequently, at first glance it appears motivated to speak about suppletion according to polarity. Describing var vs. yok (affirmative vs. negative existential) in a relation of suppletion puts the emphasis on the fact that the negative existential does indeed replace the affirmative one in many languages. However, as stated above, the status of negation as an obligatory grammatical category is typically not discussed when postulating suppletion according to polarity. Accepting suppletion according to polarity also presupposes the assumption that all predications should be negated in the same manner. Such an assumption does not hold in a cross-linguistic sense and should be discussed when bringing up this kind of suppletion.

Veselinova (2013B) proposes that negative existentials should be studied in their own right, as a separate functional domain. They are cross-linguistically extremely common. It is possible to outline a prototype for their content and the constructions they require. The fact that they tend to replace their affirmative counterparts is only one of the many features they have in common. Connected to this is the fact that negative existentials outnumber grammaticalized affirmative existential constructions: that is, negative existentials occur in $66 \%$ of a stratified language sample of 95 languages, while affirmative existentials ${ }^{3}$ are observed in $52.62 \%$ of this sample. Consequently, the occurrence of a negative existential is not contingent on an affirmative one. On the contrary, negative existentials appear belong to the very basic lexicon of human languages. In fact, they should be added to a modern Swadesh list. Veselinova (2013C) presents a cross-linguistic study of 


\section{Suppletion}

lexicalizations of negation where she shows that such lexicalizations are not random but rather can be grouped into broader semantic domains such as COGNITION (not know, not understand), EMOTIONAL ATTITUDE (not want, not like), MODALS (cannot, need not), POSSESSION/EXISTENTIAL (not have, not exist), TENSE/ASPECT (did not, not yet finished), EVALUATIVE JUDGMENT (not right, not enough), and finally NON-UTTERANCE (not speak, be silent). Lexicalizations of the domain of POSSESSION/NON-existence are by far the most frequent ones. With the exception of NON-UTTERANCE, all of these semantic and grammatical domains are cited by Zeshan (2004, p. 50) as being coded as irregular negatives in sign languages. Thus, it is clear that negative lexicalizations are organized around a limited number of cognitively salient categories. As Zeshan (2004, p. 51) points out, "events and states such as not liking, not knowing, not having, are all identifiable human experiences." This is why these concepts are often expressed by lexicalized expressions cross-linguistically regardless of language medium, be it spoken or sign.

Lexical expressions that incorporate negative polarity are prima facie examples of the similarities between lexicalization and suppletion. Similarly to the case of verbal number pairs, or with suppletion according to highly productive derivational aspect, whether we decide to call them lexicalizations of negation or cases of suppletion will depend on our notion of paradigm. But what is more important is that they be acknowledged as a crosslinguistic phenomenon in their own right, as they show a number of semantic and structural characteristics that set them apart from other linguistic features.

\subsection{Treatments of Suppletion}

All approaches to suppletion have in common the view that suppletion is closely related to frequency of use. ${ }^{4}$ The exact nature of this relationship is explained in different ways. A very strong tendency throughout the 20th century was to regard suppletion as an anomaly, something that survives because of the frequency of its forms. Suppletive forms were seen as belonging to the lexicon and were generally considered not interesting.

The school of Natural Morphology occupies a special place in the research on suppletion as a number of scholars working within this framework devoted a substantial amount of effort to this phenomenon. Their work stands out since it was done during a time when the phenomenon was generally ignored in all other theories. Still, while natural morphologists did acknowledge suppletion as a phenomenon, many of them regarded it as unnatural; those who made an attempt to find a motivation for its occurrence in language brought up reasons such as language economy as well as some psycholinguistic motivation.

A tendency that emerged toward the end of the 20th century and that remains current, is to regard suppletion as highly interesting for any theory, albeit still a challenging phenomenon. This is especially pronounced today in the framework of canonical typology. Some studies view suppletion as a well-motivated product of language change or function or both. The sub-sections below are arranged to reflect the chronological order of the history of accounts of suppletion. 


\section{Suppletion}

\subsubsection{Suppletion as an Accidental Phenomenon}

In mainstream 20th-century linguistics, suppletion is generally seen as a haphazard phenomenon with no value for any theory. For instance, Matthews (1974) considers the occurrence of suppletive forms a problem for inflectional morphological rules. Lass (1990) maintains that suppletive forms are kept in language only because they are very frequent; they do not adopt new functions and are consequently considered "marginal garbage." Spencer (1991) cites the phenomenon as the "limit" for any morpho-phonological theory and offers no further discussion. The list of references can be made much longer without adding anything new to the view expressed in many works and summarized here as follows: The occurrence of suppletion in any language is an annoyance that a linguist has to accept but need not address due to its accidental and unpredictable nature.

\subsubsection{Natural Morphology}

Natural morphology developed as a theory in the 1980s. It is a semiotically and functionally oriented school. Its major representatives are Willi Mayerthaler, Andreas Bittner, Wolfgang Dressler, and Otmar Wurzel. They explored the concept of markedness, originally formulated in Trubetzkoy (1931) for phonological systems. The natural morphology school sought to formulate principles of naturalness in morphological systems. Its domain is a specific class of universal characteristics of the human language faculty in the area of morphology. The main universal principles, as articulated in Mayerthaler (1988, pp. 2335), are: (a) principle of constructional iconicity and diagrammaticity; (b) uniform encoding: maximal when every form always has the same meaning and every meaning is represented by the same form; (c) transparency: includes both semantic transparency-the notion that the meaning of a word should be predictable from the meaning of its constituent morphemes-and morpho-tactic transparency.

The work of David Fertig (1998) is an important overview of the school of Natural Morphology as well as of the analysis of suppletion. This author points out that suppletion violates all principles of naturalness formulated by the proponents of the school and, consequently, it is completely unnatural. Still, natural morphologists devote a substantial amount of work to suppletion and suggest several extra-linguistic motivations for this phenomenon. One has to do with economy of expression, another with the concept of Nachbereich, "a proximate/adjacent area."

In the work of natural morphologists, the notion of economy is related to the fact that commonly used forms tend to be reduced. Suppletion is seen as economic, based on the claim (not always well substantiated) that suppletive forms, being commonly used, tend also to be short. Further on, the proponents of an economy account for suppletion bring in other psycho-linguistics factors, such as ease of access and greater differentiation in suppletive paradigms, that, in turn, make them easy to perceive. Consequently, suppletion can ultimately be argued to facilitate communication. An explanation for suppletion in which the economy principle is evoked can be found in Dressler (1985). Likewise, Werner (1987) claims that suppletive forms tend to be short and, hence, economical. The author sees this as a sufficient motivation for their occurrence, albeit he still considers 


\section{Suppletion}

them unnatural. In his criticism of the account based on economy, Fertig (1998, p. 1079), points out that none of these authors specify how the length of suppletive forms is to be measured or the exact ways whereby suppletive forms facilitate communication.

As already mentioned in Section 1.1 above, the idea of Nachbereich was first articulated by Osthoff (1899).The claim is that human beings tend to differentiate more between things that are close by (physically or in some psychological sense); consequently, it is also natural to refer to them by highly individuated expressions, such as the suppletive ones. Bittner (1988) brings up Nachbereich as a possible motivation for suppletion. In a similar vein, Wurzel $(1990)$ uses this concept to present suppletive forms as natural and motivated. Fertig (1998, pp. 1971-1972), in his criticism of the Nahbereich approach, brings up the point that the concept is hard to delimit in any rigorous way. Suppletion is known to affect frequent and often grammaticalizing function words such as "be," "come/ go," give," or "say," nouns denoting humans. However, as Fertig states, it is difficult to see how grammatical function words such the verb "be" or basic verbs of motion can be defined as anything close to speaker.

The accounts based on the economy principle, as well as the one using Nachbereich, have been extensively criticized and are currently seen as outdated, as reflected in the work of Fertig (1998), and see also Corbett (2007).

Thomas Markey did not formally belong to the school of natural morphology. However, his work (Markey, 1985) is mentioned here since his account for suppletion is strongly reminiscent of the one based on Nahbereich. Specifically, Markey (1985) suggests that suppletive forms are cognitively motivated as they reflect "basic syntagmatic arrangements" that are deeply rooted in human cognition. Such a hypothesis can be criticized in a similar vein as the Nahbereich account since Markey never offers any further specification of what is meant by "basic syntagmatic arrangements."

\subsubsection{Adequate Theory Formation}

The only inclusion of suppletion in generative grammar is found in Aronoff (1976) under the notion of blocking. It refers to "the nonoccurrence of one form due to the simple existence of another" (Aronoff, 1976, p. 43). It was first used to explain the nonapplication of otherwise fully productive derivational affixes. Later on, it was also used to cover suppletion. For instance the form goed is blocked by the already existing form went.

A tendency that became especially apparent toward the end of the 20th century, and is still current, is to see suppletion as a challenging phenomenon, but one that has to be theoretically accounted for; moreover, it is considered of great interest for an adequate theory formation. Carstairs-McCarthy (1992) sees suppletion as indicative of a paradigmatic relationship between different word forms and, consequently, important for the definition of word. This line of thinking is continued today within the framework of canonical typology, as discussed in Corbett (2007). Suppletion is considered of primary importance because of its diagnostic value for identifying paradigmatic relationships among different inflected forms and ultimately for defining possible words. Corbett makes a distinction 


\section{Suppletion}

between canonical and less canonical cases of suppletion. Furthermore, this author also discusses and exemplifies the interactions between suppletion and other phenomena such as syncretism, periphrasis, over-differentiation and reduplication.

\subsubsection{Frequency and the Economy Principle}

Suppletion tends to occur with very common words such as "be," "come," "go," "child," "eat," and "do." Such words tend to have a special status in language systems. In some traditions, those that are verbs are referred to as light verbs, that is, verbs with little lexical content that easily form predicates with some other expressions, typically nouns or nonfinite forms. In the literature on grammaticalization, these verbs are frequently found as sources for auxiliaries and grammatical markers. They are also high-token frequency items (as opposed to items that belong to a high-type frequency group), and it is this property that is usually evoked in accounts for suppletion in their paradigms. In English, a very large number of verbs form their past tense by adding a dental suffix: /-ed, -d/. Thus, the strategy of adding a dental suffix to form the past tense is referred to as a type. High-type frequency items usually form a large number as a class, but the tokens (individual items) per se are not necessarily very frequently used. High-token frequency items, on the other hand, may show idiosyncrasies in their inflectional patterns, but they are used very frequently in texts. Typical examples are the strong verbs in English together with the suppletive ones. Usually, in most discussions of suppletion and frequency, token, rather than type-frequency, is meant. It is very common to consider suppletion as a nonfunctional by-product of processes such as sound change. Since it affects high-token frequency items, it is also considered "immune" to analogy, because high-token frequency items are learned by rote and, thus, they are resistant to analogical leveling. Lass (1990) as well as Dressler (1985) represent this view.

A different view is represented in Bybee (1985), where suppletion is considered a result of frequency as well, but without it being the only triggering factor. Frequency is commonly cited as a general explanation for suppletion, but this claim is rarely substantiated in analyses of both concepts and pertinent evidence. In the past decade, such work was undertaken by the Surrey Morphology Group, Corbett, Hippisley, Brown, and Marriott (2001) as well as Hippisley, Chumakina,Corbett, and Brown(2004). Hippisley (2001) finds that weak and strong suppletive forms correlate differently with absolute and high frequency. Specifically, by examining both the absolute and the relative frequency of weak and strong suppletive nouns in Russian, Hippisley shows that there is a correlation between suppletion and absolute frequency; however, this correlation is significantly weaker for suppletion and relative frequency. This, in turn, calls for reconsidering established models of lexical storage.

The economy principle tends to be cited alongside frequency in some accounts of suppletion. Haiman (1983) associates this principle with two processes in language: Elements that are highly predictable tend to be eliminated, and elements that are frequently used tend to be reduced. When suppletion is accounted for in terms of the economy principle, scholars typically evoke the latter process, that is, the fact that suppletive forms tend to be concise expressions of frequently used notions. Works written by the main proponents 


\section{Suppletion}

of an economic account for suppletion are Ronnerberger-Sibold (1980), together with Dressler (1985) and Werner 1987. Ronnerberger-Sibold (1980) argues that very frequent forms are accessed by rote rather than by rule, and that the formal difference in suppletive paradigms facilitates perception. Mel'čuk (1994) considers suppletive forms to be compact expressions for high-token frequency items, and in that sense, they are economical.

\subsubsection{Suppletion as a Well Motivated Result of General Processes of Histori- cal Change}

There are linguists who view suppletion as well motivated, though not solely due to frequency of use and economy of expression. For these scholars, suppletion is a legitimate result of general processes of historical change. Gorbachevskij (1967) presents Slavonic data and makes a distinction between instances of suppletion that emerge due to reanalysis (in the author's terms "semantic convergence" and "semantic specification") and those that emerge due to sound change. Koneckaja (1973) offers a similar account based on data from Germanic languages. Deshpande (1992) presents textual evidence from Vedic texts and traces the gradual association of verbs (two or more verbs in each case) meaning "give," "speak," etc. with the aspectual category most appropriate for their meaning. Suppletive forms are shown to emerge as a result of reanalysis whereby a lexeme becomes associated with a specific grammatical category.

There are also studies showing that suppletive forms may result from analogical processes. For instance, Aski (1995) shows that the Romance verb "go" belonged to a rather restricted conjugational pattern (in her terms, morphological template) in earlier stages of Romance as well as in Vulgar Latin. By acquiring new suppletive forms, these verbs moved to more populated morphological templates. Thus, the emergence of suppletion is shown to follow general analogical developments. In a similar vein, Wełna (2001) examines the replacement of the Old English eode 'go.PST' by went in Middle English. He concludes that by acquiring a new preterite form, the paradigm of the verb go fits better with the paradigms of a number of other verbs. Thus, the introduction of a new suppletive form in the paradigm of $g o$ is considered a matter of analogy.

The work of Bybee (1985), and later on, of Fertig (1998), who builds on Bybee's ideas, represent milestones in the view whereby suppletive forms are seen as results of historical change rather than a residues surviving solely because of their frequency. Bybee (1985) relates suppletion with high token frequency. However, she also observes that the forms that increased in frequency also underwent semantic change in the sense that they acquired more general semantic content. Thus, suppletive forms emerge as part of general grammaticalization processes, rather than being retained due to their frequency alone.

In the same work, Bybee presents several ideas about the organization of paradigms, which are very important for the analysis of suppletion and for the way we model the emergence of suppletive forms in paradigms. First, she suggests that paradigms are not unstructured lists; rather, they tend to cluster around one or several forms, usually, the most frequently used as well as semantically and formally unmarked ones. Second, she 


\section{Suppletion}

suggests that the degree of relatedness among forms in a paradigm is contingent on the morpho-syntactic category they express. Both of these ideas are summarized below.

Clustering in paradigms is illustrated in (13) below by the Spanish verb dormir 'sleep.' It has a rather complex paradigm, where three of the actual forms are used as bases for the derivation of other forms duérme 3SG.PRS.INDIC,dormí 1SG.PRET.INDIC, and durmío 3SG.PRET.INDIC.

Spanish (Indo-European, Italo-Western Romance) [spa], adapted from Bybee (1985, p. 124)

\begin{tabular}{|c|c|c|c|c|}
\hline \multicolumn{2}{|r|}{ PRESENT } & PRETERITE & SUBJUNCTIVE & FUTURE / \\
\hline $1 \mathrm{SG}$ & duérmo & dormí & $\begin{array}{l}\text { IMPERFECT } \\
\text { durmiera }\end{array}$ & IMPERATIVE \\
\hline $2 \mathrm{SG}$ & duérmes & dormiste & durmieras & duerme \\
\hline $3 \mathrm{SG}$ & duerme & durmio & durmiera & duerma \\
\hline $1 \mathrm{PL}$ & dormimos & dormimos & durmieramos & durmamos \\
\hline 2 PL & dormís & dormisteis & durmierais & dormid \\
\hline PL & duermen & durmyeron & durmieran & duerman \\
\hline
\end{tabular}

For making a correct prediction for which forms would be basic in a paradigm and which would tend to be derived from them, Bybee introduces the concept of lexical autonomy. Basic forms tend to be autonomous and can, in varying degrees function as words on their own. Autonomous forms tend to be: (a) semantically and formally unmarked, in the sense formulated by Jakobson (1971), (b) very frequent and thus learned and stored by rote, or (c) morpho-phonemically irregular. "Even if a word is semantically marked, if it is so irregular that it cannot be derived from any other related words, it is autonomous" (Bybee, 1985, p. 58). Some verbs have one basic form only. However, frequent paradigms may have several bases. The latter is especially true of suppletive paradigms. Bybee not only points out the existence of clusters in paradigms, but also shows that the degree of relatedness between forms may be stronger or weaker depending on the frequency of use of individual forms. So in her model, paradigms are not only semantically and formally related forms that cluster around one or several bases but forms show various degrees of closeness or distance from the base depending on their frequency of use and autonomous status. The observation that frequently used forms tend to be autonomous is very well born by suppletive paradigms, according to data in Veselinova (2006, pp. 78-87) and also a short example from Fur, a language from Sudan. In this language, the verb "kill" has different stems for present and past; its paradigm is further complicated, however, by the fact that the third person singular of the past tense has a special form that is completely distinct from the other two stems. 


\section{Suppletion}

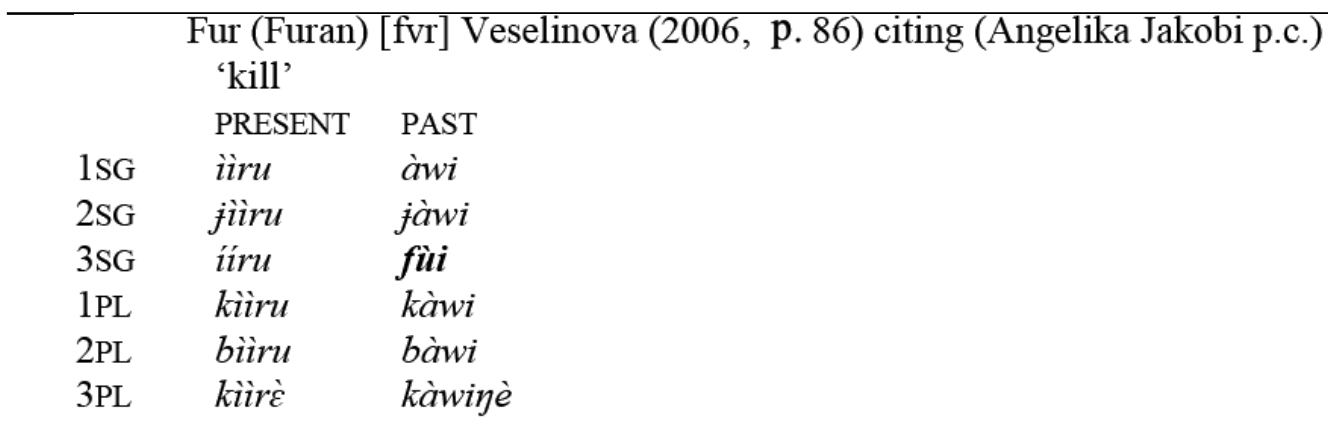

If we think about the most frequent way a verb such as "kill" would be used, it is most probably the use when one reports the fact that somebody killed something or somebody. So from a functional perspective, a special form the 3SG PAST is fully motivated.

As mentioned above, Bybee suggests that the degree of relatedness among the forms of a paradigm depends on the morpho-syntactic category they express. Specifically, she suggests the semantic categories relevant for verbs can be arranged on a scale according to two parameters: the relevance of meaning of a certain category to the meaning of the stem and the way it affects the meaning of a verb. This scale has gained currency as the "relevance hierarchy" presented in (15).

Semantic relevance hierarchy, adapted from (Bybee, 1985 , p. 24)

Valence $>$ voice $>$ aspect $>$ tense $>$ mood $>$ NAgr $>$ PAgr $>$ GAgr

$\mathrm{NAgr}=$ number agreement; $\mathrm{PAgr}=$ person agreement; GAgr $=$ gender agreement

The relevance hierarchy predicts that categories on its left-hand side are (starting with Valence) are most relevant for the meaning of a verb and will consequently make the largest change of meaning to the verb stem. Subsequently, categories such as valence and voice rarely become inflectional but are rather derivational categories in many languages. Aspect also makes a great change in the meaning of a verb, but it is more general than valence, so it does become inflectional or close to inflection in many languages. Tense and various kinds of agreement bear least semantic change to the verb stem; thus they tend to be inflectional, and their expression will often be at a greater distance from the stem than that of the categories on the left hand of the hierarchy.

One of the most important predictions made by examining the degree of relatedness among forms in a paradigm is that inflectional splits are more likely to occur along major inflectional categories, such as aspect and tense, and less likely to occur along minor inflectional categories, such as person-number agreement. As shown in Veselinova (2006), suppletive paradigms generally conform to the cross-linguistic generalizations about markedness and autonomous forms in paradigms. Suppletion in verb paradigms is very common with categories such as tense, aspect, and imperative; suppletion according to person-number of subject or object is observed very seldom. The autonomous forms in suppletive paradigms are always those that are cross-linguistically unmarked with regular verbs but that also obey Bybee's relevance hierarchy. 


\section{Suppletion}

Fertig (1998) develops Bybee's ideas with regard to suppletion in the following manner. This scholar suggests a distinction between general and category specific suppletion. General suppletion affects primarily grammaticalized and grammaticalizing words and can potentially be associated with any grammatical category, although it should still obey Bybee's semantic relevance hierarchy. A paradigm of a verb such as "be" in English is an example of general suppletion. Category specific suppletion results from the high relevance of one grammatical category to the meaning of a particular lexical item. The Slovene verbs "say" and "throw" cited in $(8, \mathrm{~d}-\mathrm{e})$ above are good examples of such category-specific cases of suppletion. Fertig's distinction is well born out by the typological data presented in Veselinova (2006). She refers to Fertig's general suppletion as non-categorical suppletion and to Fertig's category-specific suppletion as categorical suppletion.

\subsection{The Database on Suppletion}

The study of suppletion built mostly on Indo-European languages well through the 1980s. Mel'čuk (1994) presents the first study with a cross-linguistic profile, but it is still quite biased toward Indo-European. Since the 1990s and around the turn of the century, several large-scale cross-linguistic studies have been undertaken. The Surrey Morphology Group has put together an online database on suppletion (cf. Brown, Chumakina, Corbett, \& Hippisley(2003), in which all kinds of inflectional suppletion are covered in thirty-four genealogically and geographically different languages. Studies that focus on particular parts of speech include Veselinova (1997) on suppletion in the derivation of ordinal numerals and also Stolz (2001) on the same subject; these authors pooled their resources together for the World Atlas of Language Structures (WALS) project, Stolz and Veselinova (2013). Veselinova (2006) presents an extensive study of suppletion in verb paradigms, Bobaljik (2012) treats suppletion in adjectival comparison, and Vafaeian (2013) focuses on suppletion in nominal and adjectival paradigms. There are also a number of studies devoted to more specific cases of suppletion in particular language families, see Chumakina (2004) and also Veselinova (2013A) for an annotated bibliography.

The large-scale cross-linguistic studies mentioned above can be broadly summarized as follows. Suppletion is cross-linguistically a widespread phenomenon. In Brown et al. (2003), thirty out of the thirty-four investigated languages show some instances of inflectional suppletion.

As the reader will have noticed, specific studies have been devoted to traditional word classes such as verbs, nouns, and adjectives, which tend to be associated with inflectional or inflectional-derivational morphology. With regard to occurrence of suppletion with specific parts of speech, Bybee (1985, p. 93) makes a hypothetical remark that suppletion in noun paradigms is somewhat less common than suppletion in verb paradigms. This hypothesis is borne out by the cross-linguistic data presented in more recent studies. A comparison between the proportions of occurrence of suppletion with verbs, nouns, adjectives, and ordinal numerals, as reported in Veselinova $(1997,2006)$ and Vafaeian $(2013)$, reveals that suppletion is indeed more common with verbs than with nouns and that sup- 


\section{Suppletion}

pletion with adjectives shows a cross-linguistically substantially lower proportion than that with either verbs or nouns.

\begin{tabular}{|l|l|l|}
\hline \begin{tabular}{l} 
Table 1. Suppletion with Specific Parts of Speech \\
\hline $\begin{array}{l}\text { SUPPLETION WITH A } \\
\text { PARTICULAR PART OF } \\
\text { SPEECH }\end{array}$
\end{tabular} & $\begin{array}{l}\text { NUMBER OF LAN- } \\
\text { GUAGES/SAMPLE }\end{array}$ & $\%$ \\
\hline Suppletion in verb paradigms & $78 / 150$ & $\begin{array}{l}52 \% / \\
72 \%\end{array}$ \\
\hline $\begin{array}{l}\text { Suppletion in noun paradigms } \\
\text { Suppletion in adjectival com- } \\
\text { parison }\end{array}$ & $28 / 63$ & $44 \%$ \\
\hline $\begin{array}{l}\text { Suppletion with ordinal numer- } \\
\text { als }\end{array}$ & $38 / 44$ genera & $11 \%$ \\
\hline
\end{tabular}

Number of languages $=$ Number of languages where it is observed

I=Out of

Sample $=$ Total number of languages in a stratified sample

Some explanatory notes about Table 1 are in order. The estimate of suppletion in verb paradigms reported here is based on a conservative count and on an extended count. The conservative count includes cases of suppletion according to tense-aspect, person-number, and mood. The number of languages with these kinds of suppletion only includes 78 (52\%), out of the stratified sample of 150 languages. The extended count includes cases of suppletion according to verbal number and negative polarity. When they are included, the number of languages with some kind of suppletion in verb paradigms becomes 108 , that is, $72 \%$.

The estimate of suppletion in the derivation of ordinal numerals is based on the occurrence of suppletive first in a sample of 44 different genera (cf. Veselinova, 1997, pp. 438439). The data in Stolz and Veselinova (2013) come from 321 languages, but the sample is biased towards specific families, which is why it was not used for the calculation of a general proportion.

As the reader will have noticed, the major word classes, which tend to be associated with inflectional or inflectional-derivational morphology, are represented above. The ones that are missing are adverbs and pronouns. Adverbs are a heterogenous word class; the scope and productivity of their derivation differ widely. This is probably why speaking about 


\section{Suppletion}

suppletion in their derivation is controversial. Likewise, it is a controversial issue to what extent it is justified to bring up suppletion in relation to pronominal paradigms especially suppletion in pronominal number (cf. Corbett, 2005, for a detailed discussion). There are studies on pronominal suppletion that are focused on specific language families: cf. Koneckaja (1973), for pronominal suppletion in Germanic languages; Loi Corvetto (1989), for suppletion related to pronouns in Romance languages; Hill (2015) on suppletion according to case in pronouns in Indo-European languages.

The cross-linguistically well attested suppletion with verb, nouns, adjectives, and ordinal numerals outlined in Table 1 shows clear correlations with specific grammatical categories, lexemic groups, and finally language and geographical areas. The suppletive patterns for each part of speech are summarized in separate sub-sections: 1.4.1 FOR SUPPLETION IN VERB PARAGIDMS, 1.4.2 FOR SUPPLETION IN NOMINAL PARADIGMS, 1.4.3 FOR SUPPLETION WITH ADJECTIVES, AND FINALLY, 1.4.4 FOR SUPPLETION IN THE DERIVATION OF ORDINAL NUMERALS.

\subsubsection{Suppletion in Verb Paradigms}

Suppletion in verb paradigms reflects the distinction suggested by Fertig (1998), in that we observe cases of general suppletion and cases of category-specific suppletion. General suppletion is observed mostly with grammaticalized or grammaticalizing verbs, that is verbs that have acquired or are acquiring the status of an auxiliary. Examples of general suppletion are, for instance, the paradigms of the English verb "be" or the French verb être 'be.' An extreme case of a paradigm, where all forms can be seen as autonomous, can be illustrated by the Basque verb izan 'be' in (16) below.

\begin{tabular}{|c|c|c|}
\hline \multicolumn{3}{|c|}{ Basque (Isolate, Europe) [eus] (King, 1994, p. 363) } \\
\hline & PRESENT & PAST \\
\hline $1 \mathrm{SG}$ & naiz & nintzen \\
\hline $2 \mathrm{SG}$ & zara & zinen \\
\hline $3 \mathrm{SG}$ & $d a$ & $z a$ \\
\hline 1PL & gara & ginen \\
\hline 2PL & zarete & zineten \\
\hline 3PL & dira & ziren \\
\hline
\end{tabular}

The verb izan 'be' in Basque is one of the main auxiliary verbs used in many periphrastic constructions.

Category-specific suppletion is most often observed with tense-aspect categories and imperative mood.

- Tense and aspect, as in Irish and Modern Greek, in (17) and (18) respectively. 


\section{Suppletion}

\begin{tabular}{|c|c|c|c|c|}
\hline \multicolumn{5}{|c|}{$\begin{array}{l}\text { Irish (Indo-European, Celtic) [gle] (Dillon and Ó Cr } \\
\text { teim 'go' }\end{array}$} \\
\hline & PRESENT & IMPERFECT & PAST & FUTURE \\
\hline $1 \mathrm{SG}$ & téim & théinn & chuas & raghad \\
\hline $2 \mathrm{SG}$ & téann & théithéa & chuais & raghair \\
\hline $3 \mathrm{SG}$ & téann & théadh & chuaigh & raghaidh \\
\hline
\end{tabular}

Modern Greek (Indo-European, Hellenic) [ell] (Joseph \& Philipaki-Warburton,1987, p. 187) $\operatorname{le}(\mathrm{\gamma}) \tilde{o}$ 'say'

$\begin{array}{lll}\text { 1 SG PRS } & \text { le }(\mathrm{\gamma}) \tilde{o} & \text { PERFECTI } \\ \text { 1 SG PST } & \text { eleya } & \text { eipa } \\ \text { 1 SG FUT } & \theta a l e(\gamma) \tilde{o} & \theta a(\text { ei }) \text { po } \\ \text { 1 SG PERF } & & \text { exõ pei }\end{array}$

- Mood, specifically the use of a special form for the imperative as in Egyptian Arabic.

Egyptian Arabic (Afro-Asiatic, Semitic) [arz] (Mitchell, 1962, p. 152)

'come'

$\begin{array}{ll}\text { ana geet } & \text { I come.PFV.M.SG } \\ \text { ana aagi } & \text { I come.IPFV.M.SG } \\ \text { ta?aala } & \text { come.IMP.M.SG } \\ \text { ta?aali } & \text { come.IMP.F.SG } \\ \text { ta?aalu } & \text { come.IMP.PL }\end{array}$

(20)

Kewa (Trans-New Guinea, Enga-Kewa-Kuli) [kew] (Comrie, 2003, p. 2, citing Franklin, \& Franklin, 1978, pp. 135, 145)

'give'

kala 'give to 3' = 'give him/them'

gi 'give to $1 / 2$ ' = 'give me/you'

Suppletion according to tense and aspect as well as suppletion according to imperative mood can be correlated with specific lexemic groups and geographical areas (cf. Veselinova, 2013D,2013E, 2013F).

Tense-aspect suppletion is observed with the basic verbs of motion "come/go" and with verbs meaning "be." Veselinova (2006, pp. 90-91) reports that these lexemic groups constitute half of the suppletive verbs with tense-aspect suppletion, with the verbs of motion having the lead. Other lexemic groups with tense-aspect suppletion include verbs such as "say/speak," "give," "see/watch/look," "take," and finally, "do." The explanation suggested by Veselinova brings up the fact that verbs such as "be," as well as the main verbs of motion, tend to have a special status in the grammar and lexicon in any languages. Not only are they very frequent, but they are also used with a great array of functions that set them apart from all other verbs. Thus a special encoding of paradigms that consist of in- 


\section{Suppletion}

dependent forms is to be expected. Bybee's relevance hierarchy can be evoked as well, since aspect is highly relevant for actions such as speaking, seeing/looking, giving, taking, and doing. Thus, the use of different stems to mark different aspectual distinctions for these verbs is functionally motivated. Tense-aspect suppletion appears especially common in Western Eurasia, Papua New Guinea, and Meso-America (cf. also Veselinova, 2013D).

Veselinova (2006, p. 139) reports that suppletive imperatives are observed with nine lexemic groups, the most dominant being again the basic verbs of motion "come/go," followed by verbs such as "give." This author argues that this distribution can be used as an argument when describing suppletion as a functionally motivated phenomenon, since one of the most common uses of imperative forms is exactly with verbs of motion. Hence separate expressions for this function are motivated. Comrie (2003) offers a discussion of recipient person suppletion with the verb "give" and an account based on grammaticalization of deictic distinctions. Suppletion according to imperative is very frequent in all families of the African continent, the eastern parts in particular. However, it is also frequent in the eastern Uralic languages, as well as the languages of the Balkans and the languages of the Caucasus (cf. Veselinova, 2013E).

Suppletions according to tense-aspect and imperative mood, and likewise suppletion according to negative polarity and verbal number (see Sections 1.2.5 and 1.2.6, for arguments on whether to consider lexical expressions of the latter two categories as cases of suppletion) recur in many different languages around globe (see Veselinova, 2006, 2013B). Conversely, suppletion according to person or number of subject, person-number of object, mood, other than imperative, or voice are attested, but appear in a handful of languages in Veselinova's 2006 sample. They are illustrated below by a single example each, starting with Daga, a language spoken in the Milne Bay District of Papua New Guinea. In this language, we observe the rare instantiation of the occurrence of a separate stem for each value of the category of person.

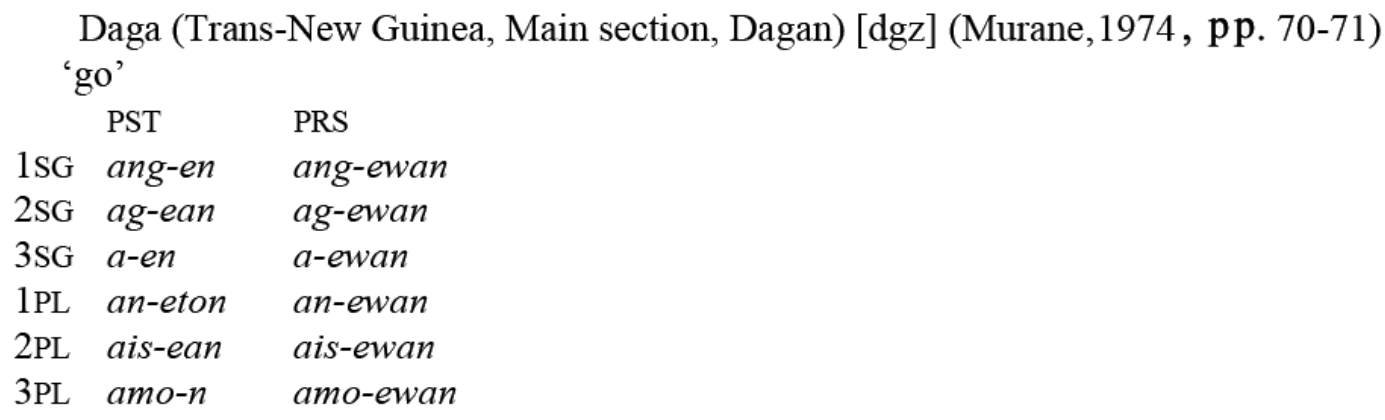

- Person-number of object as in Usan 


\section{Suppletion}

\begin{tabular}{lll}
\hline \multicolumn{3}{c}{ Usan (Trans-New Guinea, Madang-Adelbert Range) [wnu] (Ger Reesink, p.c.) } \\
& OBJ-hit-Ss 5 & OBJ-hit-2/3.DS \\
1SG.OBJ & ya-nam- $b$ & ya-nam- $a$ \\
2SG.OBJ & na-nam- $b$ & na-nam- $a$ \\
3SG.OBJ & wa-ram- $b$ & wa-ram- $a$ \\
1PL.OBJ & inin-garam- $b$ & inin-garam- $a$ \\
2PL.OBJ & anin-garam- $b$ & anin-garam- $a$ \\
3PL.OBJ & i-garam- $b$ & i-garam- $a$
\end{tabular}

- Form of object (bound or free, definite or indefinite) as in Bukiyip (23), where suppletion is conditioned by the use of bound or free object. The relevant verb stems appear in bold style in the example below.

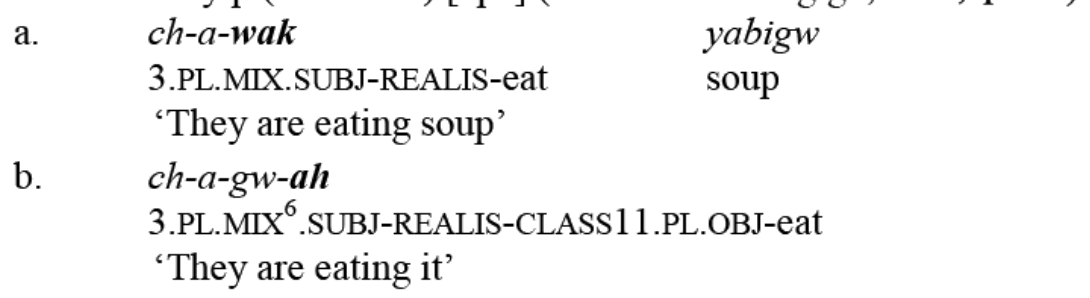

- Mood, specifically the use of a special form in subjunctive and similar moods, illustrated below by Finnish.

Finnish (Uralic, Finnic) [fin] (Païvi Juvonen, p.c.)

'be'

ol-en be-1.SG.PRESENT

ol-in be-1.SG.IMPERFECT

ol-isi- $n$ be-COND.PRESENT-1.SG

liene- $n$ be.POTENTIAL-1.SG

- Voice as in Malagasy

Unlike familiar European languages where the passive verb is the marked form in the opposition active vs. passive, as in (25) below, it is the opposite in Malagasy; the active verb is the morphologically more complex one and is typically derived by various means from the verb root, as in (26).

(25)

English

a. Tim broke the bottle

b. The bottle was broken by Tim

(26) 


\section{Suppletion}

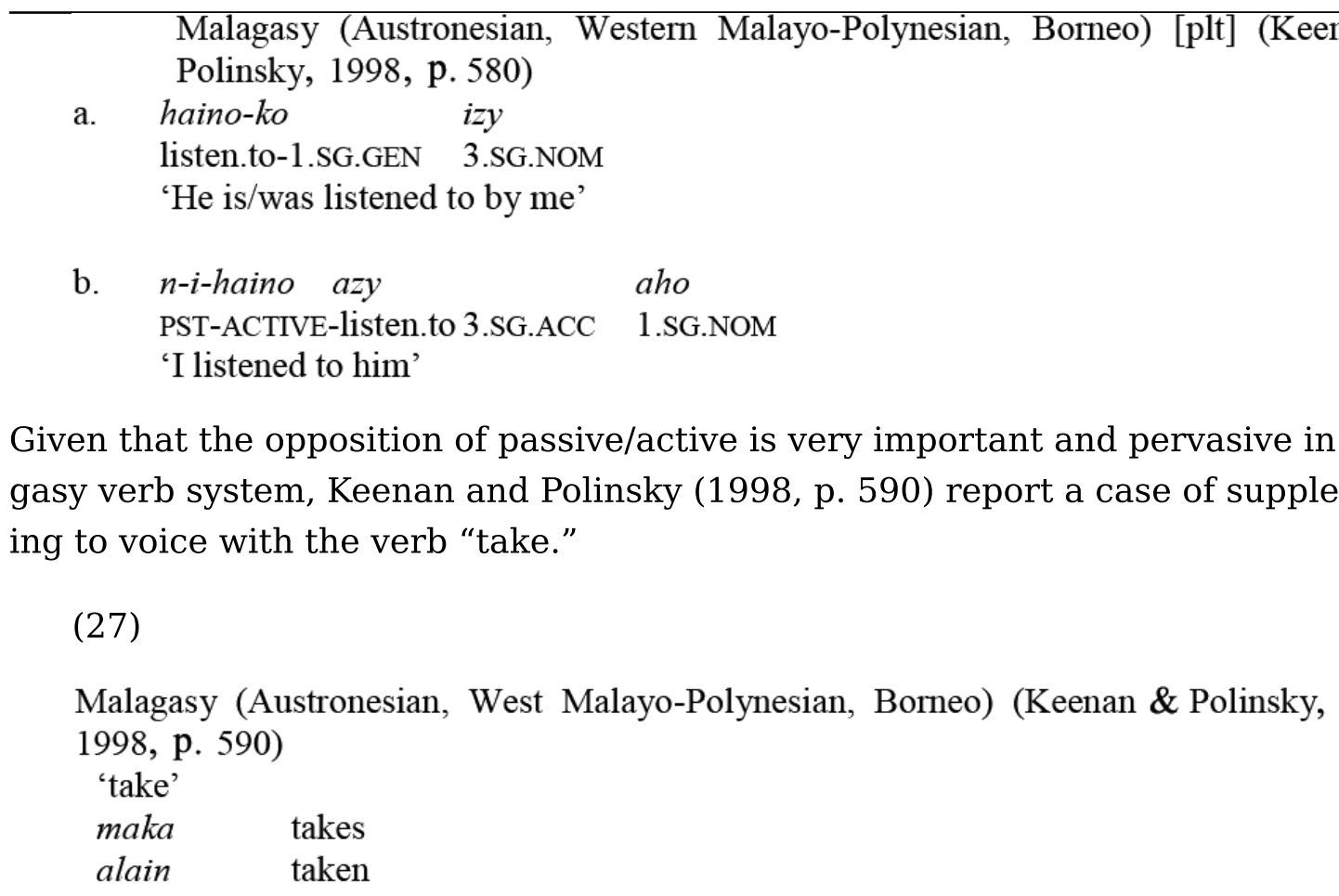

Finally, suppletion according to honorific levels is observed in several languages that have a system for indicating the speaker's knowledge of his/her social relationship with the addressee. This is illustrated by data from Korean.

\begin{tabular}{|c|c|c|}
\hline \multicolumn{3}{|c|}{ Korean (Isolate, Asia) [kor] (Sohn, 1994, p. 360) } \\
\hline PLAIN & DEFERENTIAL & Gloss \\
\hline mekta & capswu-si-ta & ‘eat' \\
\hline & $t u-s i-t a$ & \\
\hline cata & cwumwu-si-ta & 'sleep' \\
\hline cwukta & tolaka-si-ta & ‘die’' \\
\hline & $\begin{array}{l}\text { cakkoha-si-ta } \\
\text { pvelseva-si-ta }\end{array}$ & \\
\hline
\end{tabular}

\subsubsection{Suppletion in Nominal Paradigms}

Suppletion with nouns shows a somewhat lower cross-linguistic frequency than suppletion in verb paradigms cf. Table 1. Still, as demonstrated by Vafaeian (2013), nominal suppletion is a stable cross-linguistic phenomenon in the following senses. First, suppletive nouns are observed in a substantial part, $44 \%$, of a stratified language sample, see also Map 1 for the geographical distribution. Second, both the lexemic groups as well as the grammatical categories expressed by suppletion are well delimited, and in a sense predictable. Specifically, nouns denoting humans are much more likely to show suppletion in their paradigms than nouns denoting non-humans; in fact, the presence of nouns denoting non-humans and non-animates is very low. Among the 16 general lexemic groups listed in Vafaeian (2013, p. 121), only two fall in this latter category, "house" and "tortilla"; two others denote frequently domesticated animals, such as "cow" and "dog." The re- 


\section{Suppletion}

maining 12 lexemic groups with nominal suppletion include kin terms and nouns such as "child," "woman," and "person"; the noun "child" appears to be cross-linguistically most prone to suppletion, and specifically suppletion according to number. Thus the Russian noun rebënok cited in (2) is representative of a well-established cross-linguistic tendency. A couple of other illustrations follow in (29) and (30) below, cf. Vafaeian (2013, pp. 129136) for more data on suppletive nouns.

Ket (Yeniseian) [ket] (Vafaeian,2013, p.133) 'child'

SG $\quad d y l$

PL kat

Yimas (Lower Sepik Ramu) [yee] (Foley, 1991, p. 120, and cited in Vafaeian, 2013, p. 135) 'son, child, boy'

SG kalakn

DU kaymampan

PL kumpwi

Only a handful of the grammatical categories pertinent for nouns are expressed by suppletive forms. They are number, possession, and a couple of categories related to case, vocative, accusative, and ergative.

Lakhota (Siouan) [lkt] (Vafaeian, 2013, p. 133)

'mother'

1POSS ina 'my mother'

2POSS nihu 'your mother'

Tariana (Arawakan, Northen Maipuran, Japucan-Columbia) [tae] (Vafaeian, 2013, p.

135)

'son's wife'

NON-VOCATIVE nurinu

VOCATIVE tethu

(33)

Archi (Nakh-Dagestanian, Lezgic) [aqc] (Vafaeian, 2013, p.131; citing Brown et al., 2003)

'father'

ABSOLUTIVE.SG abttu

ERGATIVE.SG ummu 


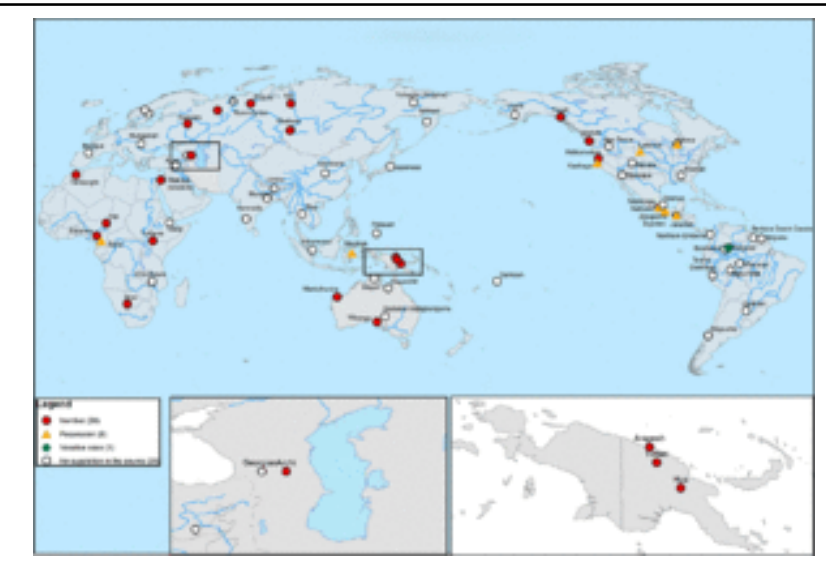

Map 1. Suppletion in noun paradigms.

Data from Vafaeian $(2010,2013)$.

The occurrence of nominal categories with suppletion is not random. Following Bybee's (1985) reasoning, Vafaeian (2013, p. 122) suggests that the categories involved in noun suppletion can be used to formulate a grammatical relevance hierarchy for nouns. Based on the current data, such a hierarchy would state that number is the feature most relevant for a nominal stem, followed by possession. Case is a syntactic category, and as such, it does not make a significant change in the meaning of a noun; consequently the use of suppletive forms to mark case appears to be relatively rare, cross-lingusitically. Vafaeian (2013) argues that the number may, in fact, have a semantic effect, especially with nouns such as "child." Specifically, the individual characteristics of a single child, such as age and sex, are not necessarily present or equally discernible when talking about a group of children. In Vafaeian's data, there are two other nouns "woman" and "person" that regularly use suppletive forms for the formation of their plurals. The account Vafaeian suggests for the regular occurrence of a suppletive form to express the plural children can be applied and extended to other nouns, which denote human individuals in a general way. Just as suggested in the account for using very distinct forms when talking about an individual child vs. a group of children, the particular characteristics of an individual tend to become irrelevant when speaking about a group of individuals. In fact, data show that, in the presence of a regularly derived plural and a collective noun, the collective may come to be used as the sole expression of the plural. Central and South Siberian Turkic languages provide a good example of such a development.

The case of person vs. people in Central and South Siberian Turkic (Eyüp Bacanlı, p.c.)

\begin{tabular}{|c|c|c|}
\hline & INDIVIDUAL & PLURAL \\
\hline a. Altai & $k i z ̌ i$ 'person' & - \\
\hline b. Saha & kihi 'person' & kihiler 'persons' \\
\hline c. Tuva & $k i z ̌ i$ 'person' & kižiler 'persons' \\
\hline d. Khakas & $k \breve{v} z \breve{l}$ 'person' & kĭzŭler 'persons' \\
\hline e. Karaim & $k^{\prime} i$ š $^{\prime}$ 'person' & k'išilär 'persons' \\
\hline
\end{tabular}

COLLECTIVE ulus(tar) 'people' most suppletive d'on(nor) 'people' ulus(tar) 'people' čon(nar) 'people' dunja 'people' el'liar 'people' 


\section{Suppletion}

In a strict sense, the nouns cited in (34) represent groups of semantically related words. Only the singular and the plural forms can be said to form a paradigm, while the singulars and the collectives are usually described to be in the same relationship as person and people are in English. However, it should be noted that in Altai the plural form *kižiler does not exist. The form kihiler in Saha is reduced to sporadic occurrences. In Tuva the frequencies of both kižiler and ulus(tar) are almost equal. At this point, there are no comparable data for Khakas and Karaim (Eyüp Bacanlı, p.c.). Furthermore, in both Altai and Saha, the collectives in (34) are also used in compounds that are said to express plurality of various individuals, as shown in data in (35) and (36) below.

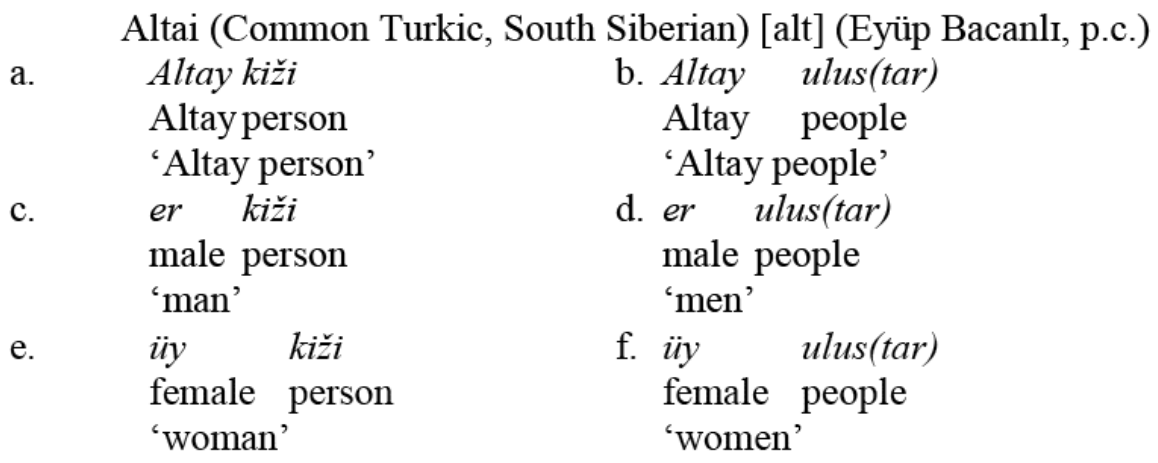

Saha (Common Turkic, North Siberian) [sah] (Eyüp Bacanlı, p.c.)
a. ulaxan kih old person
b. ulaxan d'on(nor) 'older [person]'
old people
c. Saha kihi 'older [people]/[ones]' 'Saha [person]'
e. ayan kihi-te journey person-3POSS 'passenger'
d. saha d'on(nor)
Saha people
'Saha [people]'
f. ayan d'on-o journey people-3POss 'passengers'

Thus, in Saha and Altai, we observe an emerging relationship of suppletion between the individual noun kihi/kiži and the collective d'on(nor)/ulus(tar) 'people' (from Veselinova \& Bacanlı, 2016) for further discussion of this issue.

As noted, possession comes next to number as the grammatical category, which is commonly expressed by suppletive forms. The data in Vafaeian (2013) show that it marks two kinds of distinctions. Specifically, suppletive forms can be used to distinguish between non-possessed and possessed nouns, as in (37) from Maybrat, or for different personnumber values of the nominal possessor, as in Lakhota, shown in (31) above. There are also languages such as Ewondo (38), where both kinds of suppletion are observed, according to possession. 


\section{Suppletion}

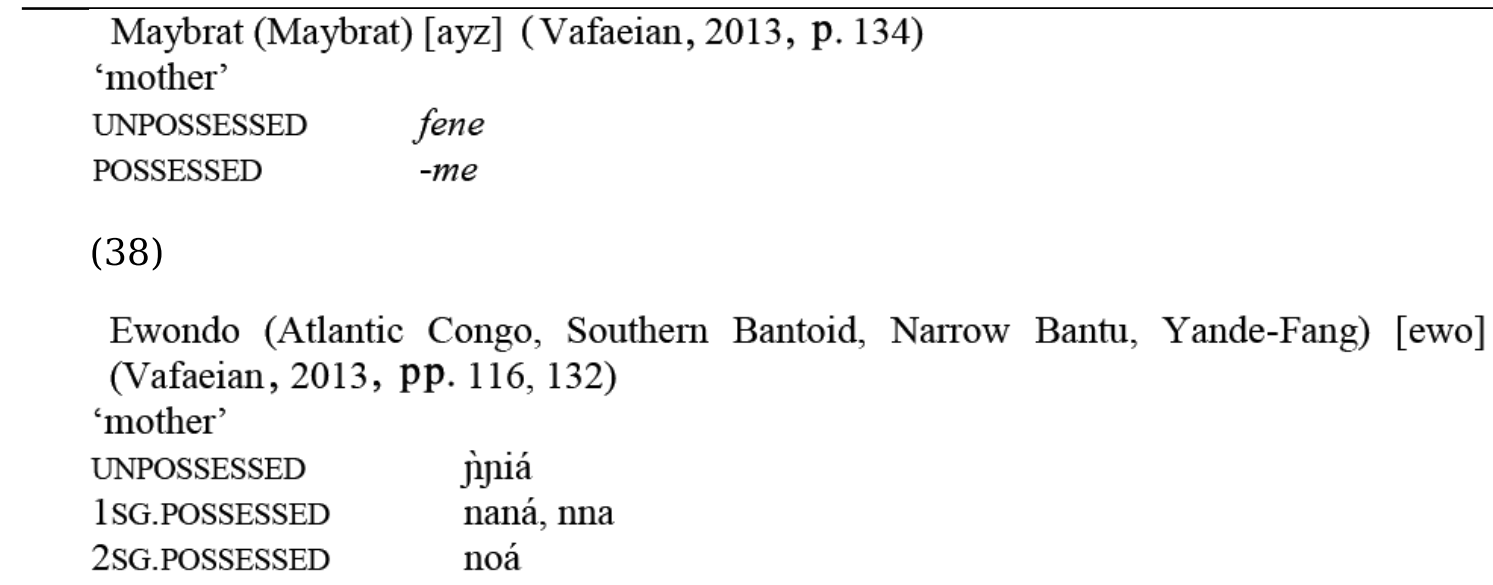

Suppletion that expresses distinctions according to possession is observed almost exclusively with kin terms. In Vafaeian's data, most of the languages where it is observed are located in North America (6 out of 8); ${ }^{7}$ one is in Africa and one is in Western Oceania. In her data, there are more languages with suppletion whereby non-possessed and possessed nouns are distinguished. However, since her sample is relatively small, it remains to be confirmed whether this is a true cross-linguistic preference.

A detailed study of suppletion according to person-number of the possessor is found in the work of Baerman (2014). He focuses on this phenomenon as observed in 13 different families from New Guinea. Baerman also points out that it is most probably much more wide-spread than currently known (cf. Baerman, 2014, p. 442). As his work is the first detailed study of this kind of suppletion, it also sets several parameters for the analysis of this phenomenon that can be further tested on other languages. Based on the collected data from the languages of New Guinea, Baerman suggests a frequency cline for the distinctions found with this kind of suppletion. Specifically, using one form for 1st person of possessor and another for the rest of the paradigm is the most common case; next is the singling out of a 3rd person of possessor vs. the rest of the paradigm. The least common case appears to be the singling out of the 2 nd person of the possessor vs. the rest of the paradigm. Using distinct forms for every single person category of possessor is encountered as well; however, Baerman notes that this is never the sole pattern of suppletion according to possession in any language. In other words, three-way person suppletion always occurs in languages that have at least one of the patterns mentioned above.

$\begin{array}{lll} & \text { Ankave (Angan) [aak] (Baerman, 2014, p. 413) } \\ & \text { 'mother' } & \text { 'mother in law' } \\ 1 & \text { ino'ki' } & \text { neagwi' } \\ 2 & \text { ri-na'i' } & \text { ri-neagwi' } \\ 3 & \text { si-na' } i \text { ' } & \text { si-neagwi' }\end{array}$

(40) 


\section{Suppletion}

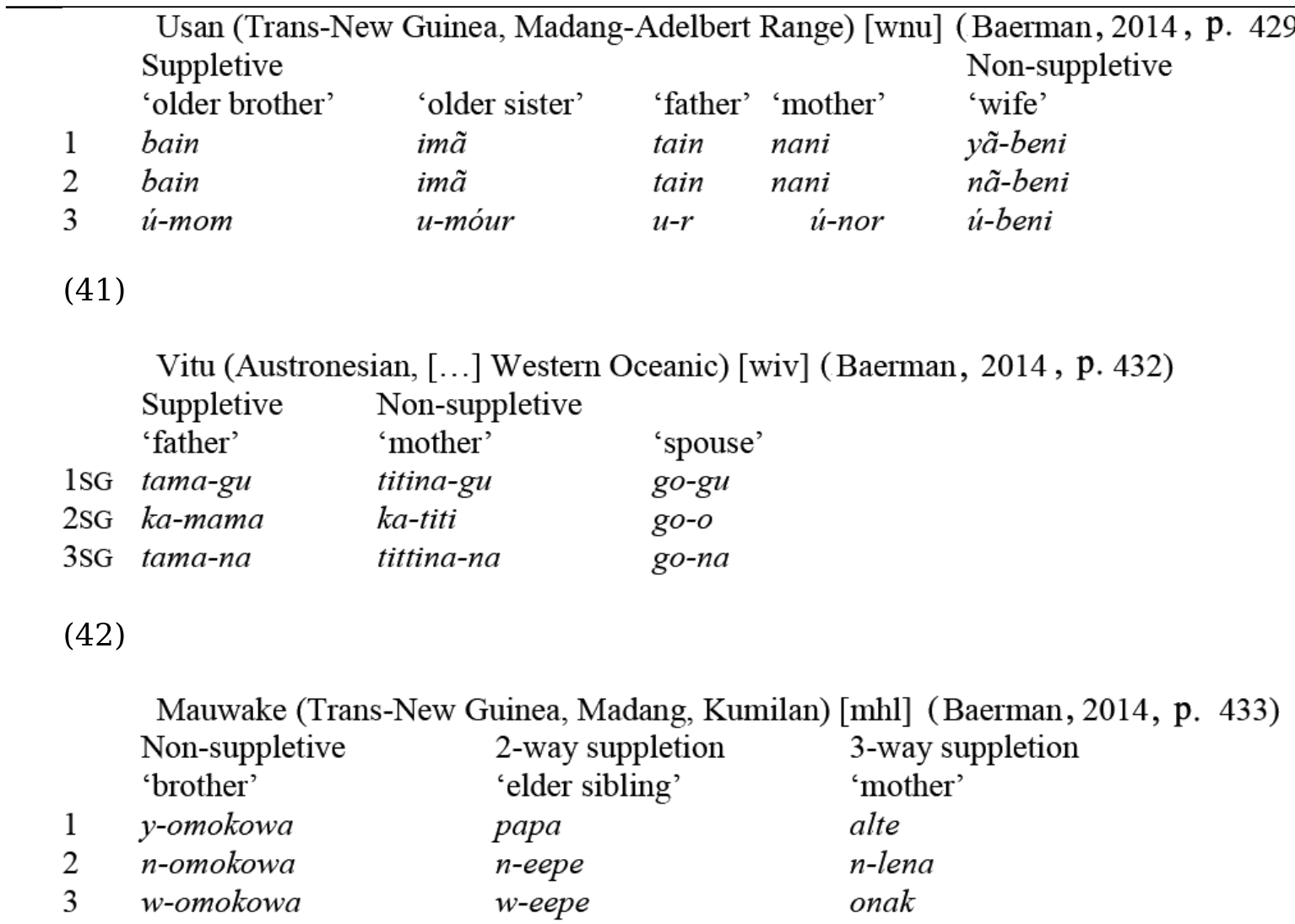

Suppletion that reflects both person and number of the possessor is also possible. Even in these paradigms, the distinction of 1st person from the rest of the paradigm emerges as a very important one. Thus Baerman (2014, p. 436) suggests to view this phenomenon in terms egocentric reference; this notion was initially introduced by Dahl and KoptjevskajaTamm (2001). These scholars show that expression of possession with kinship terms has a pragmatic motivation in discourse. Specifically, kinship terms are animate nouns, which resemble proper names in many of their prototypical uses. That is, they tend to be used to refer to well-known individuals in the immediate situational context. The anchor of a kinship term is the "I" of the speech act, that is, the speaker. Dahl and Koptjevskaja-Tamm state that kinship terms are egocentric and pragmatically anchored. Further on, these authors bring up the fact that, contrary to popular belief, kinship terms belong to conservative parts of the lexicon, and they are actually renewed very often. Common sources for their renewal, as in listed in Dahl and Koptjevskaja-Tamm (2001, p. 219), include (a) nursery language/Motherese; (b) loans from other languages; (c) slang; and (d) diminutives. Suppletive forms in the paradigms of kinship terms can often be traced back to these registers. Vafaeian (2013, p. 123) also notes that the referent of a possessed kinship term such as "my mother," "your mother" may be quite different from the referent of non-possessed generic "mother." Thus this kind of suppletion has a semantic and functional motivation. The principle of egocentricity can be also evoked when seeking an explanation for the obvious tendency for singling 1st person out from the rest of the paradigm for specifically kinship terms. For a detailed discussion of egophoricty in grammar in discourse, see Dahl $(2000,2008)$. 


\section{Suppletion}

\subsubsection{Suppletion With Adjectives}

Suppletion in adjectival paradigms has been studied by Vafaeian (2013) in general and by Bobaljik (2012), with a special focus on suppletion in adjectival comparison. Vafaeian (2013, p. 126) reports suppletion in adjectival paradigms for seven languages of her stratified sample of 63 languages; that is, suppletive adjectives appear in a rather modest proportion of 11\%; see Map 2 for a geographical distribution. One common kind of adjectival suppletion is the one observed in adjectival comparison, as in the introductory English example show in (1). Another example can be given in French in (43).

\begin{tabular}{lll}
\multicolumn{3}{r}{ French (Indo-European, Italo WesternRomance) [fra] ( author data) } \\
'good' & 'pretty' \\
POSITIVE & bon & beau \\
COMPARATIVE & mieux & plus beau \\
SUPERLATIVE & meilleur & le plus beau
\end{tabular}

The other kind of adjectival suppletion is according to number, singular or plural, as in (44). That kind of suppletion is observed in three languages of Vafaeian's sample (Halkomelem [hur], Kashaya [kju], and Tariana [tae]).

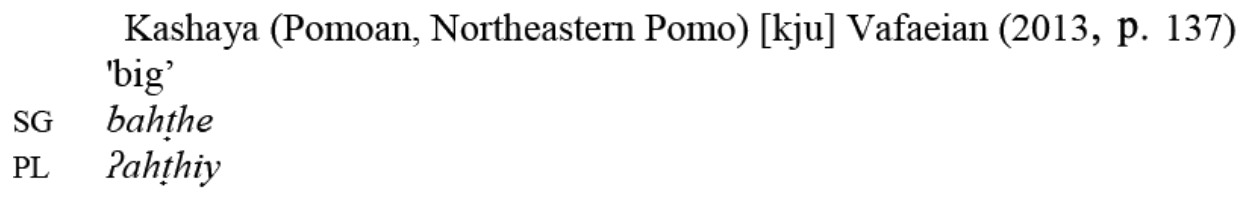

Some more complex cases include suppletion according to definiteness and number. This is illustrated by Swedish data in (45).

\begin{tabular}{|c|c|c|c|c|c|}
\hline \multirow[t]{2}{*}{ a. } & Swedish ( author data) & & \multicolumn{3}{|c|}{ stor 'big' } \\
\hline & SG & PL & SG & & PL \\
\hline & INDEFINITE DEFINITE & & INDEF & DEFINITE & \\
\hline $\mathrm{m}$ & liten lille/lilla & små & stor & store/stora & stora \\
\hline $\mathrm{n}$ & lille/lilla & små & stort & stora & stora \\
\hline f & liten & små & stor & stora & stora \\
\hline
\end{tabular}

As shown in (45) above, the Swedish adjective liten has three stems: lite- for the indefinite singular, lill-for the definite singular, and små for the plural. Compared to a regular Swedish adjective, the adjective liten is very complex. Corbett (2007, pp. 31-32) cites parallel data for the same adjective in East Norwegian. The pattern of suppletion is the same as the Swedish one; the East Norwegian form for "little" in definite noun phrase is vesle. Corbett uses the case of "little" to exemplify over-differentiation in paradigms. That is, 


\section{Suppletion}

suppletive forms can be used to distinguish between features that are otherwise not differentiated with other members of the same class.

For a diachronic account of the pattern reported in (45), see Ljunggren (1944). Börjars and Vincent (2011) offer further comparative and semantic analysis of the different adjectives that have come to form a single paradigm. The authors suggest that one of the preconditions for the emergence of suppletion is the availability of synonyms. In the case of "little/small," one of them refers to a general size property of being small in size and the other to that fact that an object may consist of small parts. In the Scandinavian case, the adjective that referred to small parts was chosen to represent the plural. Maiden (2014) presents similar facts when discussing cases of suppletion according to number with two Megleno-Romanian adjectives "big" and "small"; he also applies the same line of reasoning in his account for the emergence and presence of this kind of suppletion. So far suppletion with adjectives according to number is considered by various authors to be rare. However, a cursory look at the data in the available literature brings not only the facts reported for the Scandinavian varieties here but also for Megleno-Romanian, "little" in Middle Breton and Middle Cornish (Maiden, 2014, p. 42), Mara (Northern Australia) cited by Corbett (2007, p. 32, note 44), and finally the data from Kashaya, Halkomelem and Tariana reported by Vafaeian (2013). At this stage, it is unclear whether all these instances represent something truly sporadic and scattered or a cross-linguistic phenomenon that has gone unnoticed so far. However, the distribution outlined here suggests that a more detailed study is highly advisable.

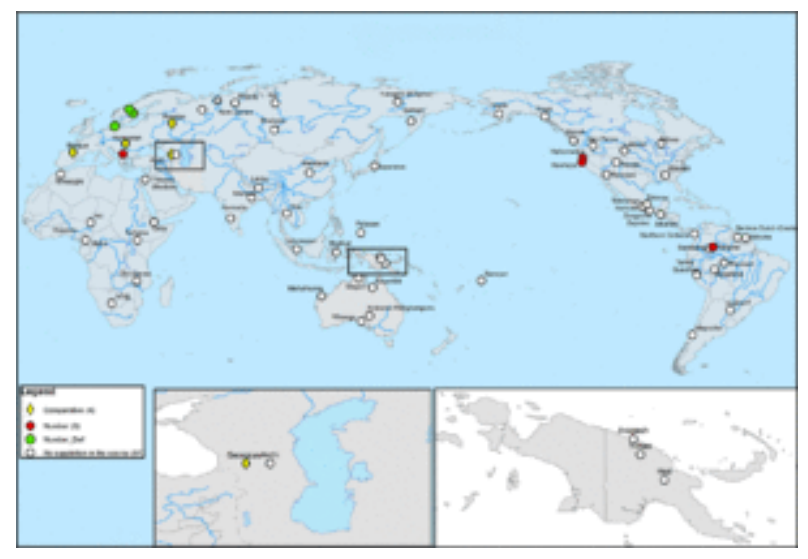

Map 2. Suppletion in adjectival paradigms.

Data from Vafaeian $(2010,2013)$ and Veselinova (this article).

Another rare type of adjectival suppletion is one that reflects the syntactic function of the adjective. In Russian, a handful of adjectives have different forms depending on their use as attributes or predicates; this distinction is informally referred to as long vs. short form of the adjective. The long form is used when the adjective is an attribute; the short one when it is a predicate. 


\section{Suppletion}

Russian (Indo-European, East Slavonic) [rus] (own data)
a. long form problema
važnaja problem
important.LONG
'an important problem'
b.
Short form pra problema byla očen' važna
This problem was very, important.SHORT
'This problem was very important'

The short and long forms of the Russian adjective "big" are sometimes expressed by completely distinct lexemes velik vs. bol'šoj; thereby, suppletion according to this parameter is observed.

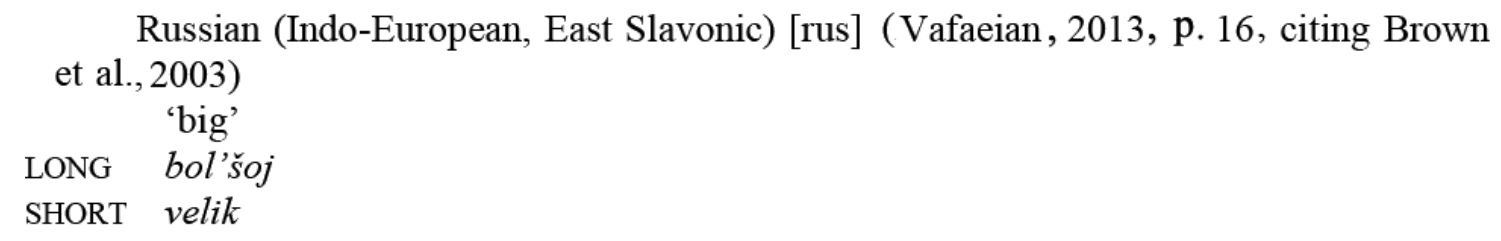

Suppletion according to definiteness as well as suppletion according to syntactic function of the adjective appear to be rare and isolated phenomena in the currently available data. But as already noted, this generalization should be checked by further research.

Similar to other kinds of suppletion, adjectival suppletion appears with a restricted set of lexical items. Specifically, the adjectives with which it is found include concepts such as "good," "bad," "big," "little," "old," and finally, the quantifiers "many" and "few." One can easily see that these adjectives fall within the set defined by Dixon (1977) as the most prototypical adjectives. As Dixon pointed out in that work, in languages that lack adjectives, the first ones to form an emergent adjective class, tend to come from four semantic domains: size, value, age, and color. In other words, if a language has very few adjectives, they will most often fall within the domains just mentioned. Comparative suppletion affects the most general adjectives that express value, size, and age. The only domain that is missing is color. But, as Vafaeian (2103, p. 127) notes, this is hardly surprising, since the kind of scalar comparison that is highly relevant for adjectives such as "good," "bad," or "old" is simply not relevant for color notions (or color notions are typically not discussed in this way).

The following can be said with regard to suppletion according to degrees of comparison. An examination of Vafaeian's data shows that the use of suppletion in adjectival comparison is observed in four languages (Basque, Georgian, Hungarian, and Russian), all of them in Europe. The same European locus of this kind of suppletion is reported by Bobaljik (2012) and also Stolz, Otsuka, Urdze, and van der Auwera(2012). Consequently, it is most probably safe to say that this is one more feature that can be added when speaking about Europe as a Sprachbund (cf. Haspelmath, 2001). This is, per se, not new, since suppletion according to comparison had been discussed as a strictly European phe- 


\section{Suppletion}

nomenon in the late 1980s (cf. Wurzel, 1987). Stolz et al. (2012, p. 30) also show that comparative suppletion is more likely to occur in the languages of Western Europe; the likelihood of finding it decreases as one travels eastward. Stolz et al. $(2012$, p. 30) also bring up the fact that there are micro-areas in Europe where this phenomenon is completely absent. They are the Balkans, Anatolia, Latvia, and Lithuania, defined in their work as "the Indo-European part of the Baltic countries." The lack of comparative suppletion in these micro-areas is attributed to contact with languages where such suppletion is missing. However, as Stolz and his colleagues also note, a lot remains to be done in the study of the role of contact in the rise or leveling of suppletion.

An important work on comparison and suppletion is found in Bobaljik (2012). This scholar examines suppletion in comparison in two different kinds of samples: a genealogically stratified one of about 148 languages and another set of 174 languages that he calls "the focused sample." The latter includes mostly languages that are known to have morphological expression of comparison. Similar to Stolz et al. and also to Vafaeian, Bobaljik (2012) suggests that suppletion in adjectival comparison has its geographic locus in Europe. He also offers several generalizations about the encountered patterns of suppletion, which he calls Comparative-Superlative Generalization. This generalization states that if a language has a suppletive comparative, it will also have a suppletive superlative. Furthermore, the most widespread pattern of suppletion in comparative constructions is that both of the suppletive roots will come [historically] from the same stem. Cases where they come from different stems are also encountered. This scholar dismisses any possibility for a functional motivation of this kind of suppletion and attributes it to principles of universal grammar.

Vincent and Börjars (1996) examine the genesis of suppletion according to comparison in Romance languages with the framework of Lexical-Functional grammar. These authors draw parallels between suppletion and periphrasis. This approach to the emergence of suppletion is worth testing and replicating in further studies.

\subsubsection{Suppletion in the Derivation of Ordinal Numerals}

Veselinova (1997), Stolz (2001), and subsequently Stolz and Veselinova (2013), show that if ordinals exist in a language and are derived from cardinal numerals, the lowest members of the set, "first" in particular, will, more often than not, be non-derived/suppletive. The figures differ somewhat in the studies just cited, but in all of them they hover between $70 \%$ and $80 \%$. This is a very high proportion for a worldwide cross-linguistic study. In fact, this tendency can be safely formulated as an implicational universal. Thus, if a language has a category of ordinal numerals, the lower members of the set, especially the term for "first," will usually be distinct from the corresponding cardinal. There are languages where the term for "first" and "second" are derived from corresponding cardinals, but they are definitely in the minority: 9\% (4 out of 44 genera) in Veselinova (1997) and $12 \%$ in the WALS sample collected by Stolz and Veselinova. 


\section{Suppletion}

Sources for suppletive "first" and "second" are strikingly uniform across the languages of the world. Veselinova (1997, pp. 443-444) lists four main sources for "first": lexemes that have a spatial or temporal meaning such as "front," "foremost," "before"; lexemes with a clearly temporal meaning such as "early/earliest," "begin"; a group that includes body part terms such as "head" or more abstract ones such as "headman," "leader," "main"; and finally, borrowings. The sources for "second" show a clear spatio-temporal grounding as well; typically, they can be traced back to terms such as "follow/following," "next," "other," "behind," "rear," "back," "last," "again," and finally to borrowings, which in turn have or have had similar senses in the source languages. When seeking an explanation to this, Veselinova and Stolz bring up the function and uses of ordinal numerals. They are typically used to indicate the arrangement of familiar objects in a sequence, or a sequence of events. This operation is completely different from counting, and consequently a separate linguistic expression is fully justified and cognitively motivated.

\subsubsection{How the Available Data Informs Our Analysis of Suppletion}

The cross-linguistic research summarized here shows that suppletion appears as a systematic cross-linguistic phenomenon in the following senses. First, the occurrences of suppletion center around a limited number of grammatical and lexical concepts. It is also possible to set up hierarchies for suppletion whereby this occurrence is captured in predictable ways. Second, suppletion is also genealogically stable and, in many instances, geographically coherent. In fact, some kinds of suppletion, such as suppletion according to tense-aspect, imperative, or comparative appear to be so sharply distinct from each other that they may be described as completely different phenomena.

Bernhard Wälchli (p.c.), as cited in Veselinova (2007, p. 147), suggests that we take it even further. Traditionally, suppletion is defined in a negative way, as an exception to a given pattern, something that does not comply with an established, and often completely hypothetical, default. However, Wälchli points out that there are different kinds of exceptions: negative and positive. Negative exceptions are not connected to other exceptions in any way; they are completely random and distributed at random. Positive exceptions can be shown to behave consistently in one or several distinct ways. Suppletion as outlined by cross-linguistic research emerges as a positive exception. Suppletion in verbal, nominal, and adjectival paradigms can be demonstrated to house an array of phenomena that are not necessarily related to each other. Furthermore, each kind of suppletion can be described with its own characteristics, which set it apart from other structural features described in typology. Studied in its own right, from a cross-linguistic perspective, suppletion has proven to be a recurrent phenomenon in well delimited grammatical domains. Thus, it need not be defined as an irregularity any more, but rather as a feature of complexity, whereby a lexical solution is chosen for the expression of grammatical categories, which are highly relevant for the meaning of particular words. 


\section{Suppletion}

\section{Critical Analysis of Scholarship}

There is a tacit, and sometimes not so tacit, assumption that all instances of suppletion represent one and the same morphological phenomenon. While this is a justified assumption for a synchronic description, it creates problems when scholars seek to come up with a unified account for all instances of suppletion. Despite all the work that has been done to date, as long as it is seen to represent a single synchronic and diachronic phenomenon, it will remain difficult to account for or even understand.

Studies on the emergence and on the cross-linguistic diversity of the suppletion show that it will be created from different diachronic processes. In many instances it is grounded in creating lexical expressions for very general concepts. Suppletive expressions have various degrees of relatedness to either grammar or lexicon. Whether they come to be seen in a paradigmatic relationship is very much dependent on analogical processes, and this is where lexicalization comes to meet morphology. As pointed out in SECTION 1.1, NOTES ON THE ORIGIN OF THE CONCEPT and also in Section 1.4.5, the synchronic label of suppletion is in fact an umbrella-notion that incorporates many phenomena, which are diachronically distinct, with very different evolutionary pathways. This needs to be acknowledged when seeking explanations; that is, instead of trying to come up with a general account for suppletion, one should approach its different manifestations on their own right.

So far nobody has done a comprehensive study on the role of language contact in the evolution of suppletion. Yet, language contact is cited as a factor that triggers the emergence of suppletion in several distinct works. Veselinova (1997, p. 442; 2006, pp.145-146) cites borrowing as one of the common sources for suppletive ordinal numerals and also for suppletive imperatives. Dahl and Koptjevskaja-Tamm (2001, p. 219) bring up borrowing as one of the common sources for renewal of kinship term. Stolz et al. (2012, pp. 25-31) discuss the areal clustering of suppletion in adjectival comparison in the languages of Europe; likewise Bobaljik (2012) emphasizes the strong European locus of this phenomenon. Hill (2015) cites language contact as one of the strong triggering factors for the development of suppletion in pronominal inflection.

Finally, there is still a great demand for work in which the phenomenon is highlighted in language acquisition, comprehension, and production. So far, the study of suppletion in these processes is typically subsumed in studies of restricted inflectional classes.

\section{Links to Digital Materials}

Brown, D., Chumakina, M., Corbett, G., \& Hippisley, A. R. (2003). Surrey suppletion

database. University of Surrey.

Chumakina, M. (2004). The notion of "possible word" and its limits: An annotated

bibliography of suppletion. Surrey Morphology Group, University of Surrey. 


\section{Suppletion}

Stolz, T., \& Veselinova, L. (2013). Ordinal numerals. The World Atlas of Language Structures Online. Max Planck Institute for Evolutionary Anthropology.

Veselinova, L. (2013d). Suppletion according to tense and aspect. The World Atlas of Language Structures Online. Max Planck Institute for Evolutionary Anthropology.

Veselinova, L. (2013e). Suppletion According to Tense and Aspect, Section 3: Suppletion in imperatives and hortatives. The World Atlas of Language Structures Online. Max Planck Institute for Evolutionary Anthropology.

Veselinova, L. (2013f). Verbal number and suppletion. The world atlas of language structures online. Max Planck Institute for Evolutionary Anthropology.

Veselinova, L. (2015) Negative existentials in the languages of the world. ArcGIS Online.

\section{Further Reading}

Carstairs-McCarthy, A. (1994). Suppletion. In S. Asher \& F. Simpson (Eds.), The encyclopedia of language and linguistics (pp. 4410-4411). Oxford: Pergamon.

Clancy, S. J. (2010). The chain of being and having in Slavic. Amsterdam: John Benjamins.

Corbett, G., Hippisley, A., Brown, D., \& Marriott, P. (2001). Frequency, regularity, and the paradigm: A perspective from Russian on a complex relation. In J. Bybee \& P. Hopper (Eds.), Frequency and the emergence of linguistic structure (pp. 201-227). Amsterdam: Benjamins Publishing Company.

Dressler, W. (1985). Suppletion in word-formation. In J. Fisiak (Ed.), Historical morphology (pp. 97-112). The Hague: De Gruyter Mouton.

Dressler, W. U. (1985). Sur le statut de la suppléance dans la morphologie naturelle. Langages, 78, 321-337.

Durie, M. (1986). The grammaticization of number as a verbal category. In V. Nikiforidou, M. VanClay, M. Niepokuj, \& D. Feder (Eds.), Proceedings of the Twelfth Annual Meeting of the Berkeley Linguistic Society, February 15-17, 1986 (Vol. 12, pp. 355-370). Berkeley.

Fertig, D. (1998). Suppletion, natural morphology, diagrammaticity. Linguistics, 36(6), 1065-1091.

Harnisch, R. (1990). Morphologische Irregulartität-Gebrauchshäufigkeit-psykische Nähe. Ein Zusammenhnag im empirischen Befund und in seiner theoretischen Tragweite. In J. M. Dosuna \& C. Pensado (Eds.), Naturalists at Krems: Papers from the Workshop on Natural Phonology and Natural Morphology, Krems July 1-7. Salamanca, Mexico: Ediciones Universidad. 


\section{Suppletion}

Hendrick, R. (1996). Some syntactic effects of suppletion in the Celtic copulas. In R. Borsley \& I. Roberts (Eds.), The syntax of the Celtic languages: A comparative perspective (pp. 75-96). Cambridge, U.K.: Cambridge University Press.

Hippisley, A. R. (2001). Suppletion, frequency, and lexical storage. Paper presented at the Linguistics Faculty Publications, University of Kentucky, Lexington, KY.

Hippisley, A. R., Chumakina, M., Corbett, G. G., \& Brown, D. (2004). Suppletion: Frequency, categories, and distribution of stems. Studies in Language, 28(2), 387-418.

Hale, K., La Verne M. Jeanne, \& Pranka, P. (1991). On suppletion, selection and agreement. In C. Georgopoulos \& R. Ishihara (eds.) Interdisciplinary approaches to language: Essays in honor of S-Y. Kuroda (pp. 255-270). Dordrecht, The Netherlands: Kluwer.

Kölligan, D. (2007). Suppletion und Defektivität im griechischen Verbum. Bremen, Germany: Hempen Verlag.

Létoublon, F. (1985). Il allait, pareil à la nuit: Les verbes de mouvement en grec: Supplétisme et aspect verbal. Paris: Klincksieck.

Maiden, M. (2004). When lexemes become allomorphs: On the genesis of suppletion. Folia Linguistica, 38, 227-256.

Palmer, F. R. (1995). Negation and the modals of possibility and necessity. In J. Bybee \& S. Fleischman (Eds.), Modality in grammar and discourse (pp. 453-471). Amsterdam: John Benjamins.

Ronnerberger-Sibold, E. (1980). Sprachverwendung-Sprachsystem Ökonomie und Wandel. Tübingen, Germany: Niemeyer.

Ronnerberger-Sibold, E. (1987). A performance model for a natural theory of linguistic change. In A. Giacalone Ramat, O. Carruba, \& G. Bernini (Eds.), Papers from the 7th International Conference on Historical Linguistics (pp. 517-533). Philadelphia: Benjamins.

Stump, G. (2001). Inflectional morphology. Cambridge, U.K.: Cambridge University Press.

Tiffou, É., \& Patry, R. (1995). La notion de pluralité verbale: Le cas du bourouchaski du Yasin. Journal Asiatique, 282(2), 407-444.

Vafaeian, G. (2010). Breaking paradigms: A typological study of nominal and adjectival suppletion. PhD thesis, Stockholm University, Stockholm, Sweden.

Veselinova, L. (1999). Suppletion in the paradigms of copula verbs. In B. Fox, D. Jurafsky, \& L. Michaelis (Eds.), Cognition and function in language (pp. 63-84). Standford, CA: CSLI Publications.

Veselinovič, E. M. (2003). Suppletion im irischen verb. Hamburg, Germany: Verlag Dr. Kovač. 


\section{Suppletion}

Vincent, N., \& Börjars, K. (1996, August). Suppletion and syntactic theory. LFG-Workshop. In M. Butt \& T. H. King (Eds.), Online Proceedings of the LFG'96 Conference (pp. 448-462). Grenoble, France: CSLI.

Wełna, J. (2001). Suppletion for suppletion, or the replacement of eode by went in English. Studia Anglica Posnaniensia, 36, 95-110.

Werner, O. (1987). Natürlichkeit und Nutzen morphologischer Irregularität. In N. Boretzky, W. Enninger, \& T. Stolz (Eds.), Beiträge zum 3. Essener Kolloquium über Sprachwandel und seine bestimmenden Faktoren (pp. 289-316). Bochum, Germany: Brockmeyer.

Wurzel, W. U. (1987). System-dependent morphological naturalness in inflection. In W. U. Dressler, W. Mayerthaler, O. Panagl, \& W. U. Wurzel (Eds.), Leitmotifs in natural morphology (pp. 56-96). Amsterdam: John Benjamins.

Wurzel, W. U. (1990). Gedanken zu Suppletion und Natürlichkeit. Zeitschrift für Phonetik, Sprachwissenschaft und Kommunikationsforschung, 43, 86-91.

\section{References}

Aronoff, M. (1976). Word formation in generative grammar. Cambridge, MA: MIT Press.

Aski, J. (1995). Verbal suppletion: An analysis of Italian, French, and Spanish to go. Linguistics, 33(3), 403-432.

Baerman, M. (2014). Suppletive kin term paradigms in the languages of New Guinea. Linguistic Typology, 18(3), 413-448.

Bittner, A. (1988). Reguläre Irregularitäten. Zeitschrift für Phonetik, Sprachwissenschaft und Kommunikationsforschung, 41, 416-425.

Bloomfield, L. (1926). A set of postulates for the science of language. Language, 2(3), 153-164.

Bobaljik, J. D. (2012). Universals in comparative morphology : Suppletion, superlatives, and the structure of words. Cambridge, MA: MIT Press.

Booij, G., Lehmann, C., \& Mugdan, J. (Eds.). (2004). Morphologie/Morphology: Ein Internationales Handbuch Zur Flexion und Wortbildung (Vol. 2). Berlin: De Gruyter.

Börjars, K., \& Vincent, N. (2011). The pre-conditions for suppletion. In A. Galani, G. Hicks, \& G. Tsoulas (Eds.), Morphology and its interfaces (pp. 239-266). Amsterdam: John Benjamins.

Boyé, G. (2006). Suppletion. In Keith Brown (Ed.), Encyclopedia of language \& linguistics (Vol. 12, pp. 297-299). Amsterdam: Elsevier

Brown, D, Chumakina, M., Corbett, G. G., \& Hippisley, A. R. (2003). Surrey suppletion database. University of Surrey. 


\section{Suppletion}

Bybee, J. (1985). Morphology. Amsterdam, Netherlands: John Benjamins.

Carstairs-McCarthy, A. (1992). Current morphology. London: Routledge.

Comrie, B. (2003). Recipient person suppletion in the verb "give." In M. R. Wise, T. N. Headland, \& R. M. Brend (Eds.), Language and life: Essays in memory of Kenneth L. Pike (pp. 265-281). Dallas: SIL International.

Conrad, R. J., \& Wogiga, K. (1991). An outline of Bukiyip grammar. Canberra, Australia: Australian National University.

Corbett, G. (2007). Canonical typology, suppletion, and possible words. Language, 83(1), $9-42$.

Corbett, G., Hippisley, A., Brown, D., \& Marriott, P. (2001). Frequency, regularity, and the paradigm: A perspective from Russian on a complex relation. In J. Bybee \& P. Hopper (Eds.), Frequency and the emergence of linguistic structure (pp. 201-227). Amsterdam: Benjamins.

Corbett, G. G. (2005). Suppletion in personal pronouns: Theory versus practice, and the place of reproducibility in typology. Linguistic Typology, 9(1), 1-23.

Corbett, G. G. (2000). Number. Cambridge Textbooks in Linguistics. Cambridge, U.K.: Cambridge University Press.

Creissels, D. (2014). Existential predication in typological perspective. Paper presented at the 46th Annual Meeting of the Societas Linguistica Europaea, Split, Croatia, September 18-21, 2013.

Dahl, O. (2000). Egophoricity in discourse and syntax. Functions of Language, 7(1), 3777.

Dahl, O. (2008). Animacy and egophoricity: Grammar, ontology, and phylogeny. Lingua, $118,141-150$.

Dahl, O., \& Koptjevskaja-Tamm, M. (2001). Kinship in gramar. In I. Baron, M. D. Herslund, \& F. Sørensen (Eds.), Dimensions of possession (pp. 201-225). Philadelphia: John Benjamins.

Delbrück, Bertold. (2010). Altindische syntax. Cambridge, U.K.: Cambridge University Press. The work was first published in 1888.

Deshpande, M. M. (1992). Justification for verb-root suppletion in Sanskrit. Historische Sprachforschung, 105(1), 18-49.

Dillon, M., \& Ó Cróinin, D. (1961). Teach yourself Irish. London: English Universities Press. 


\section{Suppletion}

Dixon, R. M. W. (1977). Where have all the adjectives gone? Studies in Language, 1(1), 19-80.

Dressler, W. (1985). Suppletion in word-formation. In J. Fisiak (Ed.), Historical semantics, historical word formation (pp. 97-112). Berlin: Mouton de Gruyter.

Fertig, D. (1998). Suppletion, natural morphology, diagrammaticity. Linguistics, 36(6), 1065-1091.

Foley, W. A. (1991). The Yimas language of New Guinea. Stanford, CA: Stanford University Press.

Frajzyngier, Z. (1993). A grammar of Mupun. Berlin: Dietrich Reimer Verlag.

Franklin, K. J., \& Franklin, J. (1978). A Kewa dictionary with supplementary grammatical and anthropological materials. Canberra, Australia: The Australian National University: Research School of Pacific Studies.

García Mayo, M. d. P., \& Villareal Olaizola, I. (2011). The development of suppletive and affixal tense and agreement morphemes in the L3 English of Basque-Spanish bilinguals. Second Language Research, 27(1), 129-149.

Gorbachevskij, A. A. (1967). K voprosy o putjax vozniknovenija suppletivnyx form v slavjanskix jazykax. Dushanbe, Tajikistan: Ministerstvo Narodnogo Obrazovanija Tadjiksoj SSR: Tadjikskij Gosudarstvenyj Universitet im. V. I. Lenina.

Haiman, J. (1983). Iconic and economic motivation. Language, 59(4), 781-819.

Haspelmath, M., \& Sims, A. (2013). Understanding Morphology. London: Routledge.

Haspelmath, M. 2001. The European linguistic area: Standard average European. In M. Haspelmath, E. König, W. Oesterreicher, \& W. Raible (Eds.), Language typology and language universals / Sprachtypologie und sprachliche Universalien / La typologie des langues et les universaux linguistiques (pp. 1492-1507). Berlin: De Gruyter.

Herrity, P. (2000). Slovene: A comprehensive grammar. London: Routledge.

Hill, E. (2015). Suppletion replication in grammaticalization and its triggering factors. Language Dynamics and Change, 5(1), 52-91.

Hippisley, A. R. (2001). Suppletion, frequency, and lexical storage. Paper 1. Linguistics Faculty Publications, University of Kentucky, Lexington.

Hippisley, A. R., Chumakina, M., Corbett, G. G., \& Brown, D. (2004). Suppletion: Frequency, categories, and distribution of stems. Studies in Language, 28(2), 387-418.

Jakobson, R. (1971). Signe zéro. In R. Jakobson (Ed.), Selected writings II: Word and language (pp. 211-219). The Hague, Netherlands: Mouton. Jakobson's essay was originally published in 1939. 


\section{Suppletion}

Joseph, B. D., \& Philipaki-Warburton, I. (1987). Modern Greek. London: Croom Helm.

Juge, M. (1998). On the rise of suppletion in verbal paradigms. In S. Chang, L. Liaw, \& J. Ruppenhofer (Eds.), Proceedings of the Twenty-Fifth Annual Meeting of the Berkeley Linguistics Society, 12-15 February 1999 (pp. 183-194). Berkeley: Berkeley Linguistics Society.

Keenan, E. L., \& Polinsky, M. (1998). Malagasy. In A. Spencer \& A. Zwicky (Eds.), Handbook of morphology (pp. 563-624). Oxford: Blackwell.

King, A. R. (1994). The Basque language: A practical introduction. Reno: University of Nevada Press.

Koneckaja, V. P. (1973). Suppletivism v germanskix jazykax. Moskva: Izdatel'stvo “Nauka.” Lass, R. (1990). How to do things with junk: Exaptation in language evolution. Journal of Linguistics, 26, 79-102.

Ljunggren, K. G. (1944). Adjektiven liten och små. Arkiv för nordisk filologi, 58, 47-61.

Loi Corvetto, I. (1989). Anomalie e paradigmi: Il suppletivismo nelle lingue romanze. Annali della Facoltà di Magistero Quaderno. Cagliari, Italy: University di Cagliari.

Maiden, M. (2014). Two suppletive adjectives in Megleno-Romanian. Revue Romane, $49(1), 32-52$.

Markey, T. L. (1985). On suppletion. Diachronica, 11(1), 51-66.

Martin, S. E. (1975). A reference grammar of Japanese. New Haven, CT: Yale University Press.

Matthews, P. H. (1974). Morphology: An introduction to the theory of word structure. Cambridge, U.K.: Cambridge University Press.

Mayerthaler, W. (1988). Morphological naturalness. Ann Arbor, MI: Karoma.

Mel'čuk, I. (1994). Suppletion: Toward a logical analysis of the concept. Studies in Language, 18(2), 339-410.

Mitchell, T. F. (1962). Colloquial Arabic: The living language of Egypt. London: English Universities Press.

Mithun, M. (1988). Lexical categories and the evolution of verbal number. In M. Hammond \& M. Noonan (Eds.), Theoretical morphology (pp. 211-233). San Diego, CA: Academic.

Murane, E. (1974). Daga grammar: From morpheme to discourse. Norman, OK: Summer Institute of Linguistics of the University of Oklahoma. 


\section{Suppletion}

Osthoff, H. (1899). Vom Suppletivwesen der indogermanischen Sprachen. Heidelberg, Germany: J. Hörning.

Ronnerberger-Sibold, E. (1980). Sprachverwendung-Sprachsystem Ökonomie und Wandel. Tübingen, Germany: Niemeyer.

Rudes, B. (1980). On the nature of verbal suppletion. Linguistics, 18, 655-676.

Sohn, H. (1994). Korean. London: Routledge.

Spencer, A. (1991). Morphological theory. Oxford: Basil Blackwell.

Stolz, T. (2001). Ordinalia-Linguistische Neuland. Ein Typologenblick auf die Beziehung zwischen Kardinalia und Ordinalia une die Sonderstellung von EINS und ERSTER. In B. Igla \& T. Stolz (Eds.), "Was ich noch sagen wollte...” A multilingual festskrift for Norbert Boretzky on occasion of his 65th birthday (pp. 507-530). Berlin: Akademie Verlag.

Stolz, T., Otsuka, H., Urdze, A., \& van der Auwera, J. (Eds.). (2012). Irregularity in morphology (and beyod). Berlin: Akademie Verlag.

Stolz, T., \& Veselinova, L. (2013). Ordinal Numerals. The World Atlas of Language Structures Online. Leipzig: Max Planck Institute for Evolutionary Anthropology.

Testen, D. (1997). The suppletive imperative of Arabic “come.” In M. Eid \& R. R. Ratcliffe (Eds.), Perspectives on Arabic linguistics X: Papers from the Tenth Annual Symposium on Arabic Linguistics (pp. 173-187). Amsterdam: John Benjamins.

Trubetzkoy, N. (1931). Die phnologischen Systeme. Travaux de cercle linguistique de Prague, 4, 96-116.

Underhill, R. (1976). Turkish grammar. Cambridge, MA: The MIT Press.

Van Schaaik, G. (1994). Turkish. In P. Kahrel \& R. van den Berg (Eds.), Typological Studies in Negation (pp. 35-50). Amsterdam: John Benjamins Publishing Company.

Vafaeian, G. (2013). Typology of nominal and adjectival suppletion. STUF:Language Typology and Universals, 66(2), 112-140.

Veselinova, L. (1997). Suppletion in the derivation of ordinal numerals: A case study. In B. Bruening (Ed.), Proceedings of the Eighth Student Conference in Linguistics (SCIL-8) (pp. 71-92). Cambridge, MA: MITWPL.

Veselinova, L. (2006). Suppletion in verb paradigms. Typological Studies in Language 67. Amsterdam: John Benjamins.

Veselinova, L. (2007). Suppletion from a typological perspective. In M. Miestamo \& B. Wälchli (Eds.), Broadening the horizons and redefining the foundations (pp. 127-152). Berlin: Mouton de Gruyter. 


\section{Suppletion}

Veselinova, L. (2013a). Suppletion. In M. Aronoff (Ed.), Oxford bibliographies in linguistics. New York: Oxford University Press.

Veselinova, L. (2013b). Negative existentials: A cross linguistic study. Italian Journal of Linguistics: Special Issue on Existential Constructions, 25(1), 107-146.

Veselinova, L. (2013c). Lexicalized negative senses: A cross-linguistic study. Paper presented at the 10th Biennial Conference of the Association for Linguistic Typology, Leipzig, Germany, August 15-18.

Veselinova, L. (2013d). Suppletion according to tense and aspect. The World Atlas of Language Structures Online. Leipzig: Max Planck Institute for Evolutionary Anthropology.

Veselinova, L. (2013e). Suppletion According to Tense and Aspect, Section 3: Suppletion in imperatives and hortatives. The World Atlas of Language Structures Online. Max Planck Institute for Evolutionary Anthropology.

Veselinova, L. (2013f). Verbal number and suppletion. The World Atlas of Language Structures Online. Max Planck Institute for Evolutionary Anthropology.

Veselinova, L., \& Bacanll, E. (2016). Plural marking in Turkic languages: Synchrony and Diachrony. Türkbilig, 31, 1-46.

Vincent, N., \& Börjars, K. (1996, August). Suppletion and syntactic theory. LFG-Workshop. In M. Butt \& T. H. King (Eds.), Online Proceedings of the LFG'96 Conference (pp. 448-462). Grenoble, France: CSLI.

Wełna, J. (2001). Suppletion for suppletion, or the replacement of eode by went in English. Studia Anglica Posnaniensia, 36, 95-110.

Werner, O. (1987). Natürlichkeit und Nutzen morphologischer Irregularität. In N. Boretzky, W. Enninger, \& T. Stolz (Eds.), Beiträge zum 3. Essener Kolloquium über Sprachwandel und seine bestimmenden Faktoren (pp. 289-316). Bochum: Brockmeyer.

Wurzel, W. U. (1987). Zur Morphologie der Dimensionsadjektive. In M. Bierwisch \& E. Lang (Eds.), Grammatische und konzeptuelle Aspekte von Dimensionsadjektiven (pp. 459516). Berlin: Akademie der Wissenschaften.

Wurzel, W. U. (1990). Gedanken zu Suppletion und Natürlichkeit. Zeitschrift für Phonetik, Sprachwissenschaft und Kommunikationsforschung, 43, 86-91.

Zeshan, U. (2004). Hand, head, and face: Negative constructions in sign languages. Linguistic Typology, 8(1), 1-58. 


\section{Suppletion}

\section{Notes:}

(3.) By grammaticalized existential constructions, I mean all kinds of special constructions that are used to express bare existence; this includes constructions such as the English one with a dummy subject There are cars on the street, those where existence may be (optionally) expressed by juxtaposition, as for instance in Russian, Na ulitse mašiny 'There are cars on the street.' Grammaticalized existential constructions are by no means universal; in many languages, mere existence is expressed by an intransitive sentence cf. Oneida Ka-nákle-? oskvnu:tú literally 'deer are there dwelling,' meaning 'There are deer' I 'Deer exist'; cf. Creissels (2014) for a detailed discussion of affirmative existential constructions.

(4.) This section overlaps to a large extent with the section with the same title in Veselinova (2013a).

(7.) These languages are Jacaltec [jac], Kashaya [kju], Lakhota [lkt], Anishnabeemowin [oji] (inclusive code), Zapotec [zai], Tetelcingo Nahuatl [nhg]. Languages outside North America where this kind of suppletion is observed include Ewondo [ewo] (Cameroon) and Maybrat [ayz] (Indonesian Papua).

\section{Ljuba N. Veselinova}

Linguistics, Stockholm University 